\title{
APPROACHES TO MIMIC THE COMPLEXITY OF THE SKELETAL MESENCHYMAL STEM/STROMAL CELL NICHE IN VITRO
}

\author{
A.R. Pereira ${ }^{1,2}$, D. Trivanović ${ }^{1,2}$ and M. Herrmann ${ }^{1,2, *}$ \\ ${ }^{1}$ IZKF Group Tissue Regeneration in Musculoskeletal Diseases, University Clinics, Würzburg, Germany \\ ${ }^{2}$ Orthopedic Center for Musculoskeletal Research, University of Würzburg, Würzburg, Germany
}

\begin{abstract}
Mesenchymal stem/stromal cells (MSCs) are an essential element of most modern tissue engineering and regenerative medicine approaches due to their multipotency and immunoregulatory functions. Despite the prospective value of MSCs for the clinics, the stem cells community is questioning their developmental origin, in vivo localization, identification, and regenerative potential after several years of far-reaching research in the field. Although several major progresses have been made in mimicking the complexity of the MSC niche in vitro, there is need for comprehensive studies of fundamental mechanisms triggered by microenvironmental cues before moving to regenerative medicine cell therapy applications. The present comprehensive review extensively discusses the microenvironmental cues that influence MSC phenotype and function in health and disease - including cellular, chemical and physical interactions. The most recent and relevant illustrative examples of novel bioengineering approaches to mimic biological, chemical, and mechanical microenvironmental signals present in the native MSC niche are summarized, with special emphasis on the forefront techniques to achieve bio-chemical complexity and dynamic cultures. In particular, the skeletal MSC niche and applications focusing on the bone regenerative potential of MSC are addressed. The aim of the review was to recognize the limitations of the current MSC niche in vitro models and to identify potential opportunities to fill the bridge between fundamental science and clinical application of MSCs.
\end{abstract}

Keywords: Mesenchymal stem/stromal cells, skeletal progenitor cells, niche, in vitro models, bone, tissue engineering.

*Address for correspondence: Marietta Herrmann, IZKF Group Tissue Regeneration in Musculoskeletal Diseases, Orthopedic Center for Musculoskeletal Research, Friedrich-Bergius-Ring 15, 97076 Würzburg, Germany.

Telephone number: +499318031587Ｅmail: m-herrmann.klh@uni-wuerzburg.de

Copyright policy: This article is distributed in accordance with Creative Commons Attribution Licence (http://creativecommons.org/licenses/by-sa/4.0/).

\begin{tabular}{|c|c|c|c|}
\hline & List of abbreviations & $\begin{array}{l}\text { FasL } \\
\text { FDA }\end{array}$ & $\begin{array}{l}\text { Fas ligand } \\
\text { Food and Drug Administration }\end{array}$ \\
\hline 2D & two dimensional & Flt3 & fms like tyrosine kinase 3 \\
\hline 3D & three dimensional & $\mathrm{HCs}$ & hematopoietic cells \\
\hline $4 \mathrm{D}$ & four dimensional & HLA & human leucocyte antigene \\
\hline ALP & alkaline phosphatase & HSCs & hematopoietic stem cells \\
\hline BM & bone marrow & HSPCs & hematopoietic stem and progenitor \\
\hline BMP & bone morphogenetic protein & & cells \\
\hline CFU-Fs & colony-forming unit fibroblasts & IL & interleukin \\
\hline CXCL12 & C-X-C motif chemokine ligand 12 & iNOS & inducible nitric oxide synthase \\
\hline CXCR4 & C-X-C chemokine receptor type 4 & MAPK & mitogen-activated protein kinases \\
\hline DCCs & disseminated cancer cells & MCP-1 & monocyte chemoattractant protein- 1 \\
\hline DKK1 & Dickkopf-related protein 1 & M-CSF & macrophage-colony-stimulating \\
\hline ECs & endothelial cells & & factor \\
\hline ECM & extracellular matrix & miRNA & microRNA \\
\hline
\end{tabular}




$\begin{array}{ll}\text { MMPs } & \text { matrix metalloproteinases } \\ \text { MSCs } & \text { mesenchymal stem/stromal cells } \\ \text { M } \Phi & \text { macrophages } \\ \text { NG2 } & \text { neural/glial antigen } 2 \\ \text { OC } & \text { osteoclasts } \\ \text { OPG } & \text { osteoprotegerin } \\ \text { PDGFR } \beta & \text { platelet-derived growth factor } \\ & \text { receptor beta } \\ \text { piRNA } & \text { piwi-interacting RNA } \\ \text { PCL } & \text { polycaprolactone } \\ \text { PGA } & \text { poly(glycolic acid) } \\ \text { PLA } & \text { poly(lactic acid) } \\ \text { PLGA } & \text { poly(lactic-co-glycolic acid) } \\ \text { PMMA } & \text { polymethylmethacrylate } \\ \text { RANKL } & \text { receptor activator of NF- } \kappa \text { B ligand } \\ \text { RGD } & \text { arginylglycylaspartic acid } \\ \text { RNAi } & \text { RNA interference } \\ \text { ROS } & \text { reactive oxygen species } \\ \text { Runx2 } & \text { Runt-related transcription factor } 2 \\ \text { SCF } & \text { stem cell factor } \\ \text { SCID } & \text { severe combined immunodeficiency } \\ \text { SDF-1 } & \text { stromal cell-derived factor-1 } \\ \text { STAT3 } & \text { signal trnasduces and activator of } \\ & \text { trancription 3 } \\ \text { TRP } & \text { transient receptor potential } \\ \text { VEGF } & \text { vascular endothelial growth factor } \\ & \end{array}$

\section{Introduction}

Friedenstein and co-workers originally identified a rare sub-population of cells in the BM with the potential to proliferate in plastic-adherent colonies with a fibroblastic appearance, first designated as CFU-Fs (Friedenstein et al., 1974). Later in vivo experiments have revealed the potential of $\mathrm{BM}$-isolated adherent cells to generate de novo the BM stroma and its environment upon serial transplantation to heterotopic anatomical sites (Caplan, 1991; Owen, 1988), leading to the current concept of BM-derived MSCs.

Although the BM is the most widely recognized source of MSCs, further research has suggested the presence of MSC-like cells in other tissues, including adipose tissue (Zuk et al., 2002), peripheral blood (Tondreau et al., 2005), dental pulp (Gronthos et al., 2000), pancreatic islets (Carlotti et al., 2010), synovial membrane (Hermida-Gómez et al., 2011), periodontal ligament (Seo et al., 2004), anterior cruciate ligament (Prager et al., 2018), endometrium (Schwab et al., 2008), bursa subacromialis (Steinert et al., 2015), placenta (Fukuchi et al., 2004), umbilical cord (Baksh et al., 2007), and umbilical cord blood (Sarugaser et al., 2005). It has been further proposed that MSCs may be present in any vascularized tissue at perivascular sites (Crisan et al., 2008).

Due to their multipotency and wide dispersion in the body, MSCs are an essential element of most modern tissue engineering and regenerative medicine approaches. There are extensive reviews on the biology of the MSCs, elucidating their nature and unique properties (Bronckaers et al., 2014; Méndez-Ferrer et al., 2010; Phinney and Prockop, 2007; Prockop and Oh, 2012). In the present review, the different microenvironmental cues influencing the MSC phenotype and function either in health and disease - including cellular, chemical, and physical interactions - are discussed. In addition, the most recent in vitro culture strategies addressing the complexity of the in vivo MSC environment are summarized.

\section{The MSC identity relies on their localization}

The characterization of MSCs either ex vivo or in vivo remains difficult since there is neither a distinct definition nor a robust assay to identify MSCs in a mixed population of cells. However, the International Society of Cellular Therapy has established three main criteria that should be fulfilled by genuine MSCs in vitro. These cells should (1) exhibit plastic adherence; (2) express a set of surface markers - i.e., CD73, CD90, CD105, and lack the expression of CD45, CD34, CD14 or CD11b, CD79 $\alpha$ or CD19, and HLA-DR; (3) have the ability to differentiate in vitro into mesenchymal lineages, namely adipocyte, chondrocyte, and osteoblast (Dominici et al., 2006). These criteria are applied for the in vitro characterization and validation of putative MSCs isolated from different tissue sources; however, differences exist in MSCs isolated from various tissue origins for what concerns the clonogenecity level, proliferation rate, differentiation potential, cell surface marker expression, and, most importantly, their regenerative potential in vivo (Bianco et al., 2008; Hass et al., 2011; Raicevic et al., 2011). In fact, only cells isolated from the BM reestablish the marrow stroma upon serial transplantation in mice (Méndez-Ferrer et al., 2010; Sacchetti et al., 2007). CD146 ${ }^{+}$pericytes, firstly isolated from the BM (Bianco et al., 2008) and later from multiple vascularized human organs (Crisan et al., 2008), exhibit long-term proliferation and trilineage differentiation potential in in vitro cultures. However, pericytes, identified by the expression of the transcription factor Tbx18, maintain their identity during aging and diverse pathological in vivo settings and do not contribute to tissue regeneration (Guimarães-Camboa et al., 2017), suggesting that the plasticity of these cells observed in vitro can be in fact the result of artificial cell manipulations. Regardless of the controversy, these findings provide evidence that MSCs should not be classified as a uniform population of theoretically multipotent cells, but rather a super-family of tissuespecific committed progenitors, possibly even with a distinct developmental origin, as proposed by Robey (2017) and Sacchetti et al. (2016). Noteworthy, isolated MSCs seem to reflect an organ-specific potency and a mechanical memory from past physical 
environments, which can influence cell fate - e.g., MSCs originated from the BM are more predisposed to give rise to the skeleton, MSCs from adipose tissue to adipocytes and those from other organs to the respective native connective tissues (Sacchetti et al., 2016; Yang et al., 2014).

\section{The nomenclature debate}

Due to already identified functional and anatomical diversity of putative MSCs and the lack of robust assays, the nomenclature of these cells has been extensively debated in the field since their discovery. First named as 'colony-forming-unit fibroblasts' by Friedenstein in 1974 (Friedenstein et al., 1974), quickly their name was changed to 'marrow stromal cells' when their in vivo potential to generate de novo the complete BM structural components was proven (Owen, 1988). Caplan (Caplan, 1991) has proposed to introduce the term 'mesenchymal stem cells' due to their clonability and multilineage potential as well as their loose architecture of randomly organized cells surrounded by large amounts of ECM, which is a characteristic of mesenchymal tissues. However, the International Society for Cellular Therapy (Horwitz et al., 2005) has decided to change the term back to 'mesenchymal stromal cell', due to the inappropriate and misleading use of the term 'stem', especially in the context of cell therapy applications. Also, the term 'mesenchymal' has been lately involved in controversy since it can be easily misinterpreted with the differentiated lineages derived from the mesoderm germinal layer - i.e., skeletal muscle, bone, connective tissue, heart, and urogenital system - which do not have the same MSC differentiation potential. Given that, the scientific community has widely accepted that, for terms of clarity, the tissue of origin of the isolated MSCs should always be stated in their name (Robey, 2017; Sipp et al., 2018). Other suggested terminologies have emerged, not based on the cell's anatomical location nor their differentiation potential but on their function and application for clinics - e.g., Caplan proposal to change the name to 'medicinal signaling cells' because of their in vivo secretory function (Caplan, 2017).

\section{The dynamics of the MSC niche}

There is abundant evidence suggesting that the MSC ability to maintain themselves or to give rise to differentiated progeny is strictly governed by complex interactions within their close environment - first proposed for HSCs as stem cell niche (Schofield, 1978). The concept of a stem cell niche has later been established as an interactive structural unit, organized to facilitate cell-fate decisions in a proper spatiotemporal manner, comprising the structural and functional components of the ECM, the cellular signaling with stem adjacent cells and other environmental cues, such as gradients of hypoxia (Fig. 1) (Li and Xie, 2005; Scadden,
2006). In vivo remodeling of the stem cell niche occurs constantly during development, e.g., during skeletal development and epithelial branching morphogenesis (Rozario and DeSimone, 2010) or in adults during wound healing (Schultz and Wysocki, 2009), where both inflammatory, angiogenic, and morphogenetic factors are present, culminating in an adjustment of the mechanochemistry and cellular composition of the tissue.

\section{Age and diseases}

The dynamics of the BM niche vary strongly with age and disorder phenotypes. During aging, a quiescence-to-senescence transition occurs in niche-residing MSCs, which strongly impairs the interactive signaling network of all niche-residing cells and ultimately the complete regenerative activity (Herrmann et al., 2019). This phenomenon is driven either by the age-associated BM fat tissue expansion (Ambrosi et al., 2017) and/or by the inherent modulation of number and type of vessels in bone and BM (Watson and Adams, 2017; Zimmermann et al., 2011). The signature and proliferation capacity of MSCs is also compromised in ECM-related disorders, such as tissue fibrosis - where an excessive deposition of ECM is observed (Usunier et al., 2014) or osteoarthritis (Maldonado and Nam, 2013) - which is linked to a resilient ECM degradation mediated primarily by MMPs and to an over-activation of osteoclast activity (Maldonado and Nam, 2013). Disruption of such control mechanisms generates aberrant ECM, both structurally and mechanically altered, leading to abnormal behaviors of cells residing in the niche and, ultimately, to enormous repercussions on the overall tissue homeostasis and functionality (Bonnans et al., 2014; Cox and Erler, 2011).

$\mathrm{BM}$ niches can also be targeted by metastasizing cancer cells (discussed in more detail below), where a malignant vicious cycle between niche and tumor cells is created, adapting the ECM dynamics to each step of tumor progression (Herrmann et al., 2019; Lu et al., 2012).

\section{Cellular interactions}

MSCs gather in niches in distinct location within the BM - namely endosteal (Nakamura et al., 2010), stromal (Herrmann et al., 2019; Pereira et al., 1998), and perivascular (Winkler et al., 2010). The phenotypical similarities of MSCs within their respective niches are currently not completely known. However, the interplay with cells of different maturation and activation states from each niche must surely play a pivotal role in adult tissue dynamics.

MSC communication with ECs and HCs in the $\mathrm{BM}$, which drives the $\mathrm{BM}$ niche integrity and bone tissue homeostasis and repair, is discussed in this section. The proper reproduction of these interactions in experimental approaches is mandatory for revealing fundamental properties of the regenerative process and creating rational cell-based therapeutic 


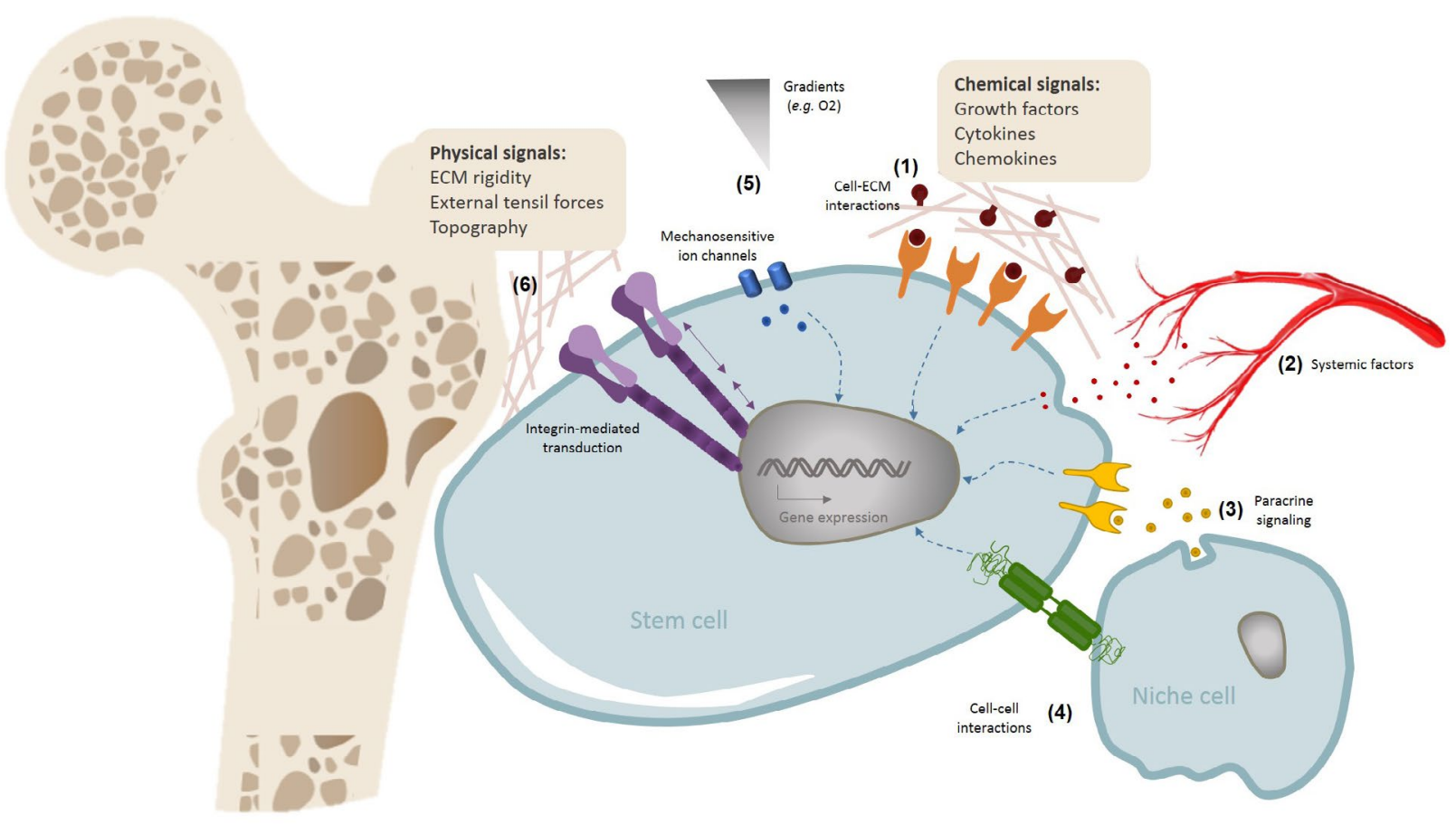

Fig. 1. MSCs' biochemical and physical interactions within the BM niche. A bidirectional synergetic cross-talk is present in the MSC niche, which is ultimately responsible for the modulation of the dynamic state of multicellular tissues - e.g., external signals can change cell DNA transcription, while, in turn, signal transduction from the interior of the cell can modify the extracellular chemistry and mechanics (Bottaro et al., 2002). These interactions may comprise: (1) receptor recognition of insoluble and soluble ECM components - such as cytokines, growth factors, morphogenetic proteins, collagenous proteins, proteoglycans; (2) systemic factors through the vascular system; (3) paracrine and endocrine signals from local or distant sources, e.g., small-molecule agonists, steroid hormones, cytokines, peptides, ions; (4) cellcell interactions with the neighbor cells, such as niche-supporting cells, immune cells, ECs, or nerve cells; (5) environmental cues, including shear forces, pH effects, oxygen tension; (6) ECM mechanotransduction based on matrix elasticity and geometry.

strategies. The understanding of the relationships between these cells is loaded by difficult definitions of certain cell phenotypes and functionalities, as they might share cell origin, i.e., mesenchyoangioblast and hemangioblats, where progenies possess endothelial and hematopoietic signatures (Angelos et al., 2018; Breitbach et al., 2018; Guibentif et al., 2017). By protecting the primitive stem cells from exhaustion and, on the other side, supporting extensive progenitor activation and differentiation when needed (Ramasamy et al., 2016), the spatial arrangement of the BM hubs is responsible for governing heterogeneity within cell populations (Crisan and Dzierzak, 2016). Cell-to-cell communication includes interaction between membrane and cytoplasm and production of growth factors and cytokines. Extracellular vesicles containing proteins, lipids, miRNA, piRNA (De Luca et al., 2016), or mitochondria transfer (MahroufYorgov et al., 2017) are important mechanisms of cell communication between MSCs and HCs (De Luca et al., 2016), as well as ECs (Gong et al., 2017; Qin and Zhang, 2017) and cancer cells (Lin et al., 2016), regulating their differentiation, migration, and survival. MSCs provide an instructive environment for angiogenesis, hematopoiesis, and osteopoiesis but also functional assistance to local and disseminated unhealthy or malignant cells (Dhawan et al., 2016; Lee et al., 2012; Roccaro et al., 2014; Xu et al., 2018).

\section{MSCs and ECs}

Stem cell behavior, tissue formation and regeneration as well as survival of bone grafts are under the control of the blood vessels, which supply oxygen and nutrients to the cells (Böhrnsen and Schliephake, 2016; Ramasamy et al., 2016). Controlled diffusion of ROS, BM blood-vessel-forming ECs and vascular integrity determine and regulate HSPC as well as MSC localization and functionality (Fehrer et al., 2007; Gomariz et al., 2018; Langen et al., 2014; Xu et al., 2018). Low permeable endosteal vessels with high integrity (H-type) differ from sinusoidal vessels with low integrity (L-type) and provide a poor ROS microenvironment, favoring HSPC maintenance, while fenestrated L-type vessels allow for HSPC respiration and mobilization (Itkin et al., 2016). Sca- $1^{+}$ and Nestin ${ }^{+}$MSCs are likewise associated with H-type vessels and sensitivity to ROS with HSPCs (Itkin et al., 2016). During aging, reduction of H-type vessels 
results in decreased levels of SCF and PDGFR $\beta^{+}$or $\mathrm{NG}^{+}$perivascular stromal cells, which is associated with a decrease in the HSPC population in the BM (Kusumbe et al., 2016). Endothelial to mesenchymal transition, an example of cell plasticity, generating pro-inflammatory ECs (Al-Soudi et al., 2017; Chen et al., 2015), is often observed in adult pathologies (Erba et al., 2017; Medici and Olsen, 2012), musculoskeletal injury (Agarwal et al., 2016), and heterotopic bone ossification (Sun et al., 2016), but is also recognized as a developmental process connecting maturation and fate of MSCs and ECs.

MSC-EC cross-talk leads to the modulation of the angiogenic response, with MSCs behaving as pericyte-like cells in the stabilization of newly formed blood vessels (Duttenhoefer et al., 2013; Herrmann et al., 2014; Loibl et al., 2014). However, current data are conflicting. MSCs attenuate activation, proliferation and angiogenesis of ECs, through the production of MMP-1 (Zanotti et al., 2016) and ROS, leading to EC apoptosis, capillary degeneration (Marfy-Smith and Clarkin, 2017; Otsu et al., 2009), and, finally, disease (Cipriani et al., 2007). In contrast, MSC-EC crosstalk stimulates proliferation and osteogenesis in MSCs and angiogenesis in ECs (Bidarra et al., 2011; Böhrnsen and Schliephake, 2016). While BM endothelial progenitors, considered to be CD34 ${ }^{+}$ or $\mathrm{CD}_{133^{+}}$cells, downregulate osteogenesis in MSCs (Duttenhoefer et al., 2015), EC progenitorderived growth factors are of critical importance for MSC engraftment, stemness, and repopulation in secondary grafts and osteogenesis (Lin et al., 2014).

\section{MSCs and HCs}

Crosstalk of MSCs and HSPCs is one of the most studied issues in physiological homeostasis and adult tissue regeneration (Chan et al., 2015; Raggatt et al., 2014), where progenies of these cells are major participants in immune response, inflammation resolution, and tissue repair. Coherency of the skeletal system and hematopoiesis maintenance (Visnjic et al., 2004) contributes to the BM as stem cell niche environment, as described above. Many mechanisms of HSPC activation by infections or various cytokines have been revealed, while the major pathways involved in steady state and emergency hematopoiesis, generating the full repertoire of immune cells, are still not understood (Boulais and Frenette, 2015; Crisan and Dzierzak, 2016). In case of an altered MSC contribution to osteoblast or adipocyte pool in the BM, biased hematopoiesis occurs through disbalanced myelo-/lymphopoiesis. Distinct stromal cell factors - such as SCF, CXCL12, Flt3 ligand, Wnt3a, angiopoietin-like proteins, thrombopoietin, and fibroblast growth factor 1 control HSPC quiescence, survival, proliferation, self-renewal, and mobilization or retention in their niche (Crisan and Dzierzak, 2016; Wohrer et al., 2014). Deletion of CXCL12 from perivascular stromal cells or osteoblasts depletes HSPCs and early lymphoid progenitors, respectively (Ding and Morrison, 2013). Leptin receptor ${ }^{+}$perivascular stromal cells are the main source of SCF and CXCL12 in the BM (Ding and Morrison, 2013; Zhou et al., 2014) and conditional deletion of SCF leads to the depletion of quiescent HSPCs (Zhou et al., 2014), while deletion of CXCL12 leads to HSPC mobilization (Ding and Morrison, 2013). Since the fast onset of HSPC differentiation in culture complicates the ex vivo amplification of HSCPs for their clinical application, development of improved HSPC-amplifying strategies where HSPCs retain their stem cell capacity are still in progress. MSCs support the proliferation of ex-vivoexpanded committed hematopoietic progenitors (Hammoud et al., 2012) and their co-culture in 3D macroporous hydrogel scaffolds, mimicking the spongy architecture of trabecular bone, results in higher CD34+ frequency (Raic et al., 2014). However, the impact of MSCs on HSPC stemness during different in vitro cultivation and repopulating activity in SCID remains unclear. MSC effects on mature or differentiated HCs are widely studied, particularly in order to reveal the immunobiology of MSCs, where their immunosuppressive capacity is attempted to be harnessed in clinical settings (Galleu et al., 2017; Simonson et al., 2015; Trento et al., 2018). On the contrary, functional adjustment of MSCs in hematologic malignancies, including acute lymphoblastic or myeloid leukemia, multiple myeloma, lymphomas, chronic myeloid leukemia, and myelodysplastic syndromes are described (Civini et al., 2013; de la Guardia et al., 2017), while it is still unknown whether malignant hematopoietic progenitors modify MSCs or if leukemia-triggering changes occur first in MSCs and the healthy marrow niche (Schroeder et al., 2016).

The murine $\mathrm{Lin}^{-} \mathrm{Sca}-1^{+} \mathrm{CKit}{ }^{+}$population, referred to as HSPCs, controls MSC differentiation, stimulating osteogenesis through the production of BMP-2 and -6 , while, in aged and osteoporotic mice, HSPCs fail to generate BMPs (Jung et al., 2008). Also, in vitro co-culturing demonstrates that murine HSPCs impact clonogenicity and favor an osteogenic gene expression profile in MSCs (Jung et al., 2008). On the other hand, differentiated HCs may also affect MSC features, directly through the modulation of their properties as constitutive cells of the mutual niche or indirectly through paracrine activity and feedback effects (Vasandan et al., 2016).

Increased megakaryocyte numbers in the BM are associated with elevated BMP-2, -4 , and -6 in mice and are followed by stimulation of MSC osteogenesis (Garimella et al., 2007). While osteoblast maturation and skeletal homeostasis might be supported by megakaryocyte (Alvarez et al., 2018; Kacena et al., 2006), data regarding the effects on osteoclastogenesis suggest inhibitory effects of megakaryocyte on osteoclast development and functions (Beeton et al., 2006; Ciovacco et al., 2010; Kim et al., 2018). In vitro studies show that 
monocytes can induce osteogenesis in MSCs through cell contact, which leads to the activation of STAT3 signaling followed by upregulation of Runx2, ALP, and Oncostatin $\mathrm{M}$ and downregulation of DKK1 in MSCs (Nicolaidou et al., 2012). From these data, it is clear that bidirectional interactions of MSCs and HCs at different developmental stages regulate local tissue functionality and their elucidation particularly contributes to the understanding of normal as well as malignant stem cell biology.

\section{MSCs and $M \phi$}

$\mathrm{M} \phi$ are phagocytic myeloid cells involved in inflammatory processes through dead cell and foreign material degradation. $\mathrm{M} \phi$ pool contains selfrenewable embryonic $M \phi$, which are established before the emergence of adult $M \phi$ which derive from marrow immature myeloid progenitors or circulating monocytes (Gomez Perdiguero et al., 2015; Yona et al., 2014). M $\phi$ are functionally specialized in lung, liver (Kupffer cells), or bone, where multinucleated OC near the bone surface participate in physiologic or pathologic bone resorption (Kim et al., 2014; Park et al., 2014; Wu et al., 2015). OC dissolve crystalline hydroxyapatite (Wenisch et al., 2003) and degrade the collagen-rich organic bone matrix (Henriksen et al., 2006). Due to their plasticity, M $\phi$ may have an anti-inflammatory (M2) or pro-inflammatory (M1) profile as well as many intermediate activation states. MSCs can facilitate monocyte to macrophage transition, but attenuate (Vasandan et al., 2016) or favor their pro-inflammatory and osteoclastic activities (Gamblin et al., 2014). MSCs induce a M2 phenotype in $\mathrm{BM}-\mathrm{M} \phi$, increasing their expression of arginase-1, IL-10, IL-4, and CD206 and decreasing the expression of IL-6, MCP-1, and iNOS (Cho et al., 2014; Takizawa et al., 2017). Through the production of major osteoclastogenic [e.g., RANKL (Biswas et al., 2018) and M-CSF (Cappellen et al., 2002)] and anti-osteoclastogenic factors [e.g., OPG (Oshita et al., 2011)], MSCs control bone resorption and remodeling (Sharaf-Eldin et al., 2016). By producing OPG and/ or FasL protein, MSCs exert a suppressive effect on osteoclastogenesis (Shao et al., 2015; Varin et al., 2013) and are proposed to be suitable cell candidates for controlling inflammation-associated bone destruction, such as rheumatoid arthritis (Oshita et al., 2011). However, the absence of osteoclastogenesis may be associated with reduced osteoblastic commitment of MSCs, endosteal osteoblast loss, and impaired homing (Mansour et al., 2012) or clonogenicity of HSPCs (Lymperi et al., 2011).

MSCs and DCCs

MSC and their progeny may facilitate neoplastic growth (Doron et al., 2018). Communication between MSCs and bone-metastatic DCCs is unclear, but it is possible that MSC s control DCC settlement in the BM as competition for niche space may exist (Dhawan et al., 2016; Gordon et al., 2014; Rossnagl et al., 2018; Shiozawa et al., 2015). Prostate cancer cells induce an osteoblastic-type lesion, while breast cancer and myeloma cells form osteolytic-type of bone lesions (Hashimoto et al., 2018). Human BM biopsies show higher $\mathrm{CD} 271^{+}$MSCs and CD31 ${ }^{+}$frequencies in the absence of DCCs in the BM of prostate cancer patients in comparison with breast cancer (Rossnagl et al., 2018). SDF-1 chemokine gradient is one of the most described explanations for tumor-to-BM homing and MSC-derived osteoblasts produce SDF-1, creating a chemo-attractant gradient for CXCR4-expressing cancer cells (Amend et al., 2016; Devignes et al., 2018). In vitro and in vivo migration assays have revealed that MSCs have tropism toward multiple myeloma cells, where MSCs promote multiple myeloma progression ( $\mathrm{Xu}$ et al., 2012). Although tumorhoming ability of MSCs suggests their utilization in anti-tumor strategies, it is still unknown how MSCs in the metastatic niche of the BM contribute to graft versus tumor reaction, one of the currently most investigated anti-tumor approaches. Exosomal transfer of miRNAs from MSCs to breast DCCs (Ono et al., 2014) induces MSCs dormancy in the BM niche. Moreover, multiple-myeloma-cell-derived exosome miRNA promotes a phenotype switch of MSCs towards a cancer-associated fibroblast state (Cheng et al., 2017). Concerning tumor persistence, there is a complex bidirectional crosstalk of MSCs and cancer cells involving various mechanisms which are still unclear but important for the understanding of peculiarities of normal and stem cell niche in tumors.

\section{ECM dynamics}

Although the crucial importance of cellular interactions with surrounding elements is recognized, a major challenge is still to understand how the chemical composition and mechanical properties of the ECM can functionally influence tissue homeostasis under physiological and pathological conditions.

Particularly, a better understanding on how disruption of ECM dynamics, i.e., both biochemical signaling and physical cues, contributes to progression of complex diseases will be important towards the development of new therapeutic targets in regenerative medicine.

\section{Biochemical interactions}

Microenvironmental cues, such as cellular interactions, the paracrine environment and ECMassociated proteins, critically influence MSC behavior via biochemical pathways. This is suggested by plenty of studies demonstrating that MSCs acquire tissue-specific characteristics when co-cultured with mature cells types (Csaki et al., 2009; Deng et al., 2008; Plotnikov et al., 2008; Schneider et al., 2011; Strassburg et al., 2010) or in complex biological substrates in vitro (Bosnakovski et al., 2006; Datta et al., 2005; Hoch et al., 2016; Suzuki et al., 2010).

The oxygen tension applied to the in vitro culture also significantly influences both MSC proliferation and differention potential in a lineage-specific matter. 
Although the published literature is quite diverse and occasionally contraditory, some studies have reported that reduced oxygen tension attenuates the MSC differentiation capacity into the osteogenic lineage (D'Ippolito et al., 2006) whilst promoting adipogenic (Fink et al., 2004) and chondrogenic differentiation (Kanichai et al., 2008; Robins et al., 2005). This correlates with the in vivo situation where chondrocytes and adipoctes reside in more hypoxic environments. Low oxygen tension also regulates MSC paracrine activity. An induced hypoxic in vitro culture stimulates an upregulation of angiogenic genes, such as VEGF and IL-6 (Hu et al., 2008). Furthermore, in hypoxia, large amounts of SDF-1, along with its receptor CXCR4, are expressed and secreted by MSCs, stimulating their mobilization and, thus, promoting MSC-homing toward damaged tissue (Liu et al., 2012; Rosenkranz et al., 2010). Likewise, tissue-specific ECM proteins have an important role as a supportive scaffold, exposing binding sites for growth factors, cell receptors ligands, proteases, etc.. In the context of bone, a type I collagen-rich ECM is required to regulate local availability of BMPs in a spatio-temporal manner and, therefore, controls osteoblast lineage progression. Specifically, integrin binding of ECMreleased BMPs to osteoblastic precursor cells initiates a MAPK-dependent signaling cascade that leads to the phosphorylation and activation of Runx2 (Yang et al., 2003), the master transcriptional regulator of the osteoblastic differentiation. Noteworthy, the ECMMSC dynamic is rather a bidirectional system, where the lineage commitment process of MSCs also induces a remodeling of the microenvironment's chemical and mechanical characteristics. Manduca et al. (2009) have investigated the role of MMPs in osteogenic differentiation, demonstrating that preosteoblastic cells sense the microenvironment through binding of $\beta 1$ integrins to fibronectin and collagen type I in the ECM, resulting in the formation of a complex with MMP-1. This complex initiates the expression of proMMP-2, required for type-I collagen and ALP proteolysis, which is involved in mineral deposition during osteogenic differentiation.

These studies emphasize the crucial role of cellmatrix interactions as highly instructive elements for stem cell biologic functions including growth, differentiation, apoptosis, and, ultimately, tissue remodeling.

The importance of the environmental mechanical properties In the context of bone, collagen fibrils comprise binding sites for mineral deposition while still keeping the structural flexibility for a tissue that would otherwise be overly rigid. Alongside, there is evidence showing that ECM physical cues not only provide support and anchorage for the cells but strongly elicit changes in gene expression and, ultimately, affect cell fate and tissue development (Chen, 2008; Engler et al., 2006; Lutolf and Hubbell, 2005). Biologically, osteocytes trapped within the matrix are the principal sensors of mechanical forces applied to the bone, with a crucial role in local mineral deposition regulation (Klein-Nulend et al., 2013). Likewise, for tissue engineering approaches, MSCs are sensitive to their substrate stiffness and able to detect its nano- and micro-topography or porosity (reviewed by Sun et al., 2012a). The transduction of these mechanical stimuli into cellular processes, otherwise known as a mechanotransduction, is accomplished through direct or indirect processes (described in detail by Sun et al., 2012a; Yim and Sheetz, 2012). Briefly, direct mechanotransduction occurs when forces applied to integrins, which are linked to the nucleus through focal adhesion interactions with the cytoskeletal protein filaments (e.g., actin and vimentin), lead to changes in gene expression through chromatin remodeling. Indirect mechanotransduction occurs either through mechanosensitive ion channels, mainly from TRP family (Ranade et al., 2015), or through integrinmediated signal pathways (Jalali et al., 2001; Schwartz, 2010), which internally couple with other growth factor pathways to regulate stem cell fate. Even with all the recent discoveries on how MSC behavior can be tailored by artificial mechanic features (refer to the next section for MSC environment modelling applications), there is still a poor understanding of the underlying mechanisms of biophysically-induced stem cell differentiation and how these dynamic complex feedbacks can be manipulated towards a therapeutic application.

\section{Modelling MSC niche complexity}

The extensive presence of MSC-like progenitor cells throughout the vascularized organs raises a wide range of possible therapeutic strategies intending to accelerate the tissue regenerative capacity following injury. The up-to-date therapeutic applications, either based on the stem-properties or on the paracrine and immunomodulatory competence of these cells, are highlighted in recent reviews (Matsumoto et al., 2016; Park et al., 2011; Peired et al., 2016; Yousefi et al., 2016). Nevertheless, in most cases, MSC-based clinical trials occur in an early phase (phase I or II) according to FDA guidelines, where the long-term safety and treatment efficacy is not yet conclusively established (Squillaro et al., 2016). Regardless of the extensive effort and advances made in MSC identity and experimental handling, there are still substantial ambiguities about their integrative functions in vivo and long-term safety, which continues to pose a major limitation on their envisioned therapeutic use. An extensive scientific knowledge of each MSC subpopulation and their interaction with the environment is still necessary to successfully translate them to the clinic. The more recent and relevant illustrative examples of novel bioengineering approaches to mimic biological, chemical, and mechanical microenvironmental signals present in 


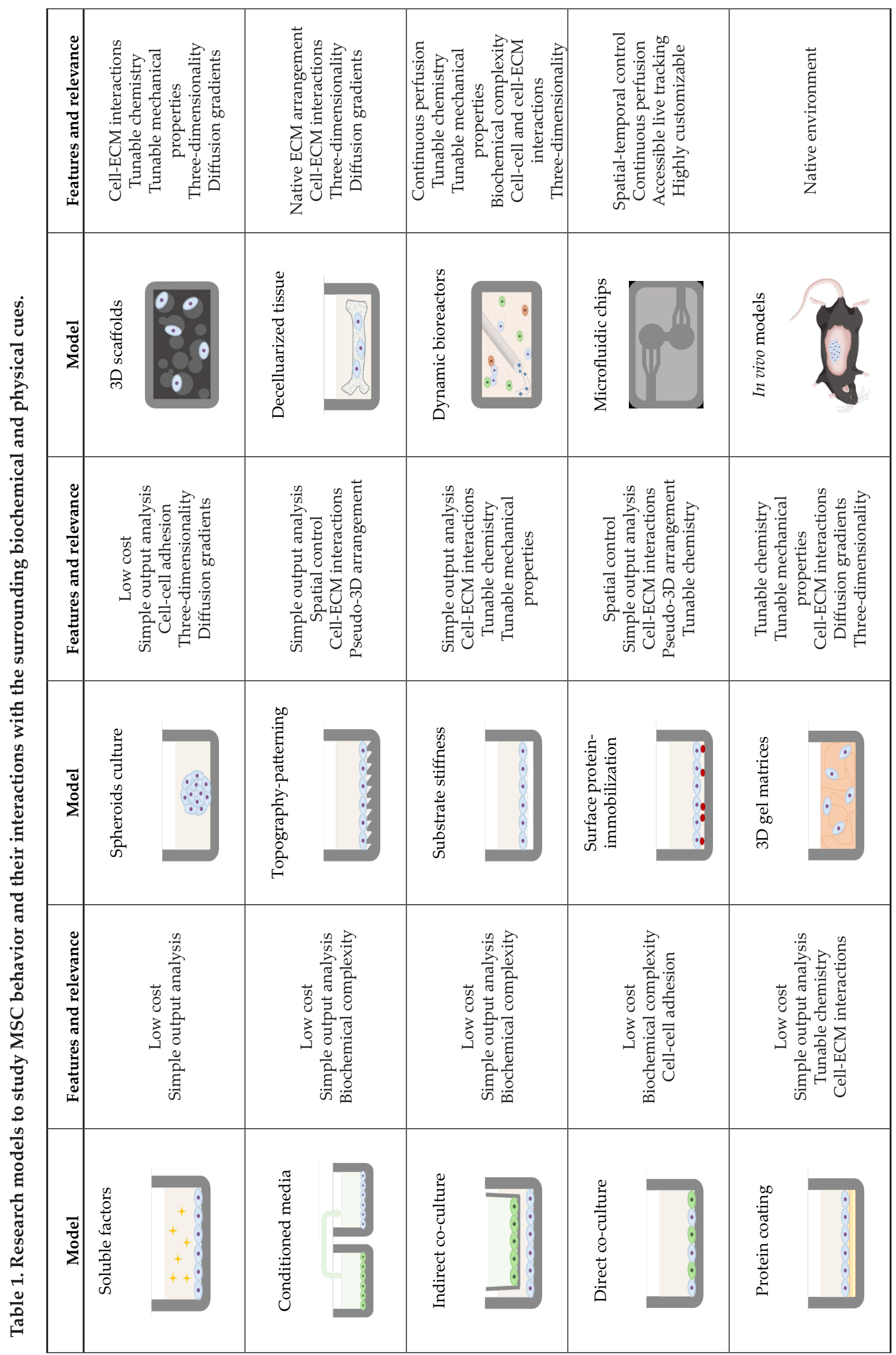


the MSC niche are summarized in this section (see Table 1). Furthermore, the current limitations are highlighted and potential opportunities to fill the bridge between fundamental science and clinical application discussed.

\section{Monolayer culture: an in vitro mechanistic tool}

Culture of an adherent cell monolayer on flat and rigid 2D substrates is a well-established straightforward technique by which cells of interest can be maintained outside the body and observed over time with a good viability of cells in culture.

\section{Paracrine factors}

To date, the simplest models for examining biological behavior of MSCs in response to microenvironmental factors are conduced by direct exposition to soluble factors (Celil and Campbell, 2005; Indrawattana et al., 2004; Kratchmarova et al., 2005; Luo et al., 2010) and conditioned media from either other cell type cultures (Chowdhury et al., 2015; Menon et al., 2007; Siciliano et al., 2015) or from tissue extracts (Chen et al., 2002). In the strictest sense, the conditioned medium refers to the cell secretome, which encompasses proteins shed from the cell surface and intracellular proteins released through non-classical secretion pathway or exosomes, including numerous enzymes, growth factors, cytokines and hormones, or other soluble mediators (Veronesi et al., 2017). Therefore, conditioned medium approaches offer the possibility of studying the paracrine interactions of complex combinations of factors, in a specific physiological or pathological environment.

\section{Co-cultures}

Co-culture techniques find countless applications in biology for studying interactions between cell populations. Overall, the co-culture systems can be set-up either by direct co-culture of both cell types or using compartmented systems, such as trans-wells or microfluidic chambers, to study solely the paracrine crosstalk and not the cell-cell signaling pathways that may occur. Many studies have explored this approach by co-culturing MSCs with mature cells in direct (Aguirre et al., 2010; Ball et al., 2004; Csaki et al., 2009; Deng et al., 2008; Strassburg et al., 2010; Takigawa et al., 2017; Wang et al., 2007) and indirect contact (Li et al., 2011; Luo et al., 2009; Wei et al., 2010). When comparing cultures of MSCs and osteoblasts alone with MSC/osteoblast co-cultures, for example, an increase in calcification over time is observed in co-culture. These results suggest the idea of a positive augmentation of the MSC differentiation process by osteoblast-secreted factors (Glueck et al., 2015).

\section{Protein-coating}

The native ECM is essentially a 3D network of fibrillar and non-fibrillar proteins, such as collagens, fibronectin, elastin, laminin, vitronectin, glycosaminoglycans, such as hyaluronan or heparin, and proteoglycans (Bason et al., 2018). Many of these ECM components are commercially available, either as complex mixtures (e.g., matrigel) or as purified proteins and are extensively applied to guide MSC differentiation in vitro (Curran et al., 2006; Phillips et al., 2010; Qian and Saltzman, 2004; Rojo et al., 2016). To achieve a high chemical complexity, MSCs are also cultured on decellularized extracellular 2D coatings, i.e., matrix produced by cells in vitro, resulting in a composition of cell-secreted components without the potentially antigenic cellular structures or contaminating DNA after collection and processing (Hoshiba et al., 2010). The enhancement of proliferation and stemness maintenance of naïve MSCs is verified in cells cultured on a basal-cultured MSC-derived decellularized ECM; while, when cultured on decellularized ECM deposited by MSCs under osteogenic differentiation, an osteogenic
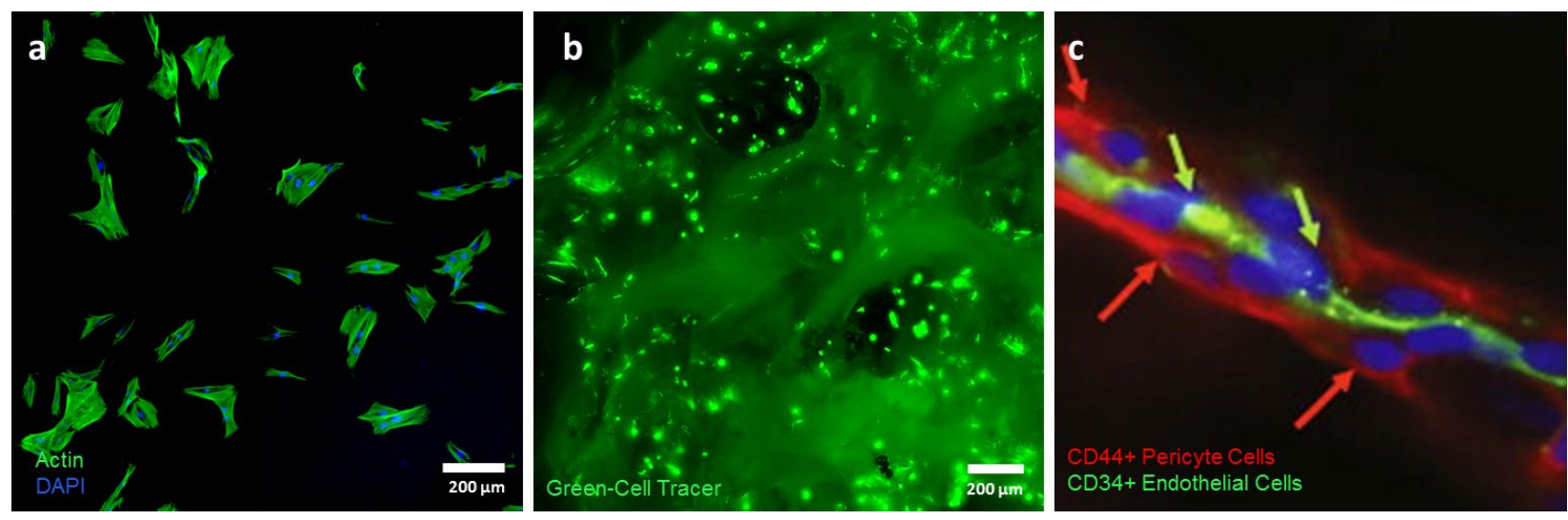

Fig. 2. Comparison of morphology and spatial organization of MSC in vitro cultures with the MSC perivascular niche in vivo. When cultured on a 2D monolayer culture of standard tissue culture polystyrene (a) MSCs acquire a stretched and flattened morphology. On the other hand, when a 3D decellularized bone scaffold is used to physically support MSC culture, (b) the cell-matrix interactions induce a different cellular distribution and arrangement which closely mimics the niche organization observed in (c) an in vivo perivascular niche [600× magnification (with permission of Crisan et al., 2008)]. 
lineage differentiation is observed in seeded MSCs cultured in the absence of dexamethasone (Rao et al., 2014).

\section{Limitations}

Although very convenient and effective for mechanistic purposes, the results from 2D cell culture models may not be representative of essential and complex features of native microenvironments. A main limitation of in vitro studies in $2 \mathrm{D}$ monolayer cultures is the lack of spatial and temporal control of multiple signals, similar to what happens in a native 3D context. Furthermore, a significant limitation of 2D cell cultures is that diffusion and transport conditions do not reflect the in vivo situation - cells grown in monolayers are exposed to a uniform environment with constant supply of oxygen, nutrients or metabolic products, which can lead to significant deviations in cellular function and response (Baker et al., 2012).

\section{Paradigm shift: mimicking MSC niche environment through third dimension}

Due to the lack of structural architecture, 2D cell culture models are substantially diverging from the in vivo state (Fig. 2). Accordingly, many research groups apply a 3D culture environment that aims to better resemble the native tissue organization.

\section{Spheroids culture}

Since the observation that chondrocytes lose their phenotype quickly in monolayer culture (Caron et al., 2012; Thompson et al., 2017), micromasses and pellet in vitro cultures have been established, allowing cells to aggregate in high densities and create their own 3D cartilaginous matrix (Cottrill et al., 1987; Johnstone et al., 1998). In addition, using a simple 3D scaffold-free spheroid culture system, Wang et al. (2009) have demonstrated that MSC multipotency can be significantly increased for both osteogenic and adipogenic lineage when compared with the conventional 2D monolayer culture. Moreover, using a perivascular-like in vitro 3D spheroid coculture system, Saleh et al. (2011) have shown that endothelial cells regulate MSC activity by maintaining quiescence and facilitating niche exit by osteogenic differentiation through activation of endogenous Wnt and BMP signaling. Other studies have reported enhanced anti-inflammatory properties after a short period of spheroid culture by increased expression of genes, such as CXCR4, which promotes adhesion, or IL-24, with tumor-suppressing properties (Bartosh et al., 2010; Potapova et al., 2008; Ylöstalo et al., 2012).

\section{Micropatterning}

A different approach being adopted is the creation of a pseudo-3D environment for MSCs using soft lithography techniques to imprint a topographypatterning in the culture substrates. This is rather a bottom-up organization approach, with cells being instructed at the molecular level. Several studies have shown increased mineralization during osteogenesis induction on micro- and/or nano-patterning growth surfaces (McNamara et al., 2010; Oh et al., 2009; Yim et al., 2007; Zhao et al., 2012). Differences in groove size as well as their geometric arrangement dictate the matrix alignment and cell morphology, resulting in a strong effect on cell proliferation and gene expression and eventually induction of bone nodules formation. Dalby et al. (2007) have shown that MSC osteogenic differentiation can be initiated with a nanopitted topographical pattern in a square geometry with a moderate level of disorder embossed into PMMA surfaces; while, on the other hand, an ordered square nanopit-pattern is proposed to mediate retention of MSC stemness (McMurray, 2011). Also, Stanciuc et al. (2018) have shown an accelerated maturation of human osteoblast maturation on micro-rough surfaces of zirconia-toughened alumina with nanoporosity obtained by selective chemical etching.

\section{Substrate stiffness}

Engler et al. (2006) have demonstrated for the first time that the substrate stiffness itself can direct MSC lineage fate. Subsequently, Pek et al. (2010) have optimized a 3D hydrogel system to guide MSC differentiation either to neural, myogenic, or osteogenic phenotypes depending on whether they are cultured in gels of elastic moduli in the lower $(7 \mathrm{~Pa})$, intermediate $(25 \mathrm{~Pa})$, or higher range $(75 \mathrm{~Pa})$, respectively. Interestingly, the matrix that optimally drives MSC differentiation to specific lineages corresponds to the stiffness of the relevant target tissue. Accordingly, tuning the elasticity of the culture material is a common strategy, adopted to control MSC fate (Du et al., 2016; Huebsch et al., 2015; Kuboki and Kidoaki, 2016; Seib et al., 2009; Wingate et al., 2012).

\section{The influence of the chemical and physical biomaterial properties}

Progress in the development of biomimetic materials have lately been chasing the complexity of the mechanical and physical-chemistry arrangement of the biomaterial itself, such as a scaffold, commonly used for tissue engineering applications. Such tissueengineered constructs not only represent potential therapeutic options for the treatment of bone defects but may also serve as a model system of the MSC naïve environment in the bone and facilitate our understanding of the interactions within the niche.

\section{D gel matrices/scaffolds}

For tissue engineering applications, the culture substrate should not only provide physical support but also present a functional surface chemistry compliant with the biological purpose. Noteworthy, the chemical composition as well as the fabrication process itself determine the final geometry, porosity, and roughness of the bulk material (Akbarzadeh and Yousefi, 2014; Loh and Choong, 2013; Pina et al., 2016). The macroporosity (pores $>50 \mu \mathrm{m}$ ) of a scaffold 
contributes to osteogenesis by facilitating cell and ion transport (Bignon et al., 2003), while microporosity (pores $<20 \mu \mathrm{m}$ ) augments bone growth by providing attachment points for osteoblasts (Bignon et al., 2003) and increasing growth factors retention upon which bone formation depends in ectopic sites (Hing et al., 2005; Woodard et al., 2007).

Commonly used natural polymers for bone tissue engineering are collagen, fibrin, alginate, silk, hyaluronic acid, and chitosan. They provide high biological recognition that may positively support cell adhesion and function, yet often lack the mechanical strength required by bone (reviewed by O'brien, 2011). Synthetic biodegradable polymers, such as PLA, PGA, and PCL are widely used due to their reproducible large-scale production, with controlled properties of strength, degradation rate, and microstructure (reviewed by O'brien, 2011). Calciumphosphate-based materials, such as hydroxyapatite and beta-tricalcium phosphate, are widely used ceramics that often shape the inorganic-phase of bone graft substitutes. Their non-toxic, non-inflammatory, non-immunogenic properties and their biological affinity (i.e., ability to form direct chemical bonds with the surrounding environment) direct tissue integration when implanted in bone defects (Ambard and Mueninghoff, 2006; Venkatesan and Kim, 2014). Besides, extensive studies of organic modifications of hydroxyapatite-based composites show the enhancement of the osteoconductive properties of the material (review by Swetha et al., 2010). For example, Zhao et al. (2006) have investigated two types of biomimetic composite materials, chitosan-gelatin and hydroxyapatite/chitosan-gelatin. They have shown that hydroxyapatite enhances protein and calcium ion adsorption - which in turn improves i) initial celladhesion and long-term growth, ii) maintains MSC stemness and iii) upon induction enhances osteogenic differentiation (Zhao et al., 2006).

\section{Engineered substrates}

The tissue engineering field provides valuable knowledge for modeling the MSC niche in vitro. Moreover, advances in protein engineering and synthetic chemistry of peptide-conjugated polymers allow the fabrication of the so-called artificial ECM constructs, which can respond to cell-secreted signals and enable proteolytic matrix remodeling (Lutolf and Hubbell, 2005). These synthetic networks are typically achieved by crosslinking of specific bioactive components in a structural mesh - e.g., (1) cell-adhesive ligands, such as integrin-binding peptides of the prototypical RGD family, resulting in an increased cell growth efficiency (Chang et al., 2009; Maia et al., 2014); (2) domains with susceptibility to degradation by cell-secreted proteases to facilitate bidirectional cell-matrix interactions (Lutolf et al., 2003); (3) binding sites for growth factor matching the pretended application (Madl et al., 2014; Park et al., 2009). Thevenot et al. (2010) have developed a PLGA scaffold with incorporated SDF-1 to enhance the recruitment of endogenous MSCs to the injury site. Likewise, Phillippi et al. (2008) have created spatially defined patterns of immobilized BMP-2 using inkjet bioprinting technology to modulate the cell organization and, consequently, their differentiation toward the osteogenic lineage.

As another powerful element, synthetic biology has recently been applied to tissue engineering modeling. Encapsulated modified cells with sophisticated tunable modular genetic switches that couple repressor proteins with an RNAi can be controlled by an external factor or specific microenvironment changes (Saxena et al., 2016; Weber and Fussenegger, 2012).

\section{$3 D$ biofabrication}

Combined knowledge of material science and 3D fabrication principles results in the advent of additive manufacturing techniques as a complex innovative approach to generate complex 3D environments with a designed and controlled arrangement of tissue morphology features and spatial distribution of cells (Bose et al., 2013; Malda et al., 2013). 3D biofabrication is becoming popular due to the ability to directly print porous scaffolds with designed shape, controlled chemistry, and interconnected porosity. Apart from inorganic scaffold manufacturing, additive manufacturing approaches are also used to explore the possibilities in fabricating scaffolds with live cells and tissues. Levato et al. (2014) have shown a combined method where MSC-laden polylactic acid microcarriers are printed by encapsulation in gelatin methacrylamide-gellan. This combined bioprinting approach allows for the improvement of the elastic modulus of the hydrogel construct, facilitating cell adhesion and survival, while supporting osteogenic differentiation and bone matrix deposition (Levato et al., 2014). Alternatively, Gurkan et al. (2014) have used another interesting approach where MSCs are encapsulated in a gelatin-based metacrylated hydrogel with addiction of BMP-2 and TGF- $\beta 1$ mimicking the fibrocartilage phase of the bone. Incorporating bioprinting technology with a nanoliter gel droplet system, this model can induce the upregulation of osteogenesis and chondrogenesis, thus making this approach a functional tissue model system (Gurkan et al., 2014).

\section{Decellularized tissue}

Although a variety of different materials and composites are available, to achieve a physiologically relevant protein and structural complexity, whole organ or tissue decellularization techniques are investigated. These natural scaffolds preserve the complex biochemical and biomechanical ultrastructure of the native tissue and can be recellularized to generate a new functional tissue or organ (Crapo et al., 2011; Lund et al., 2017). Particularly, decellularized bone is used as a scaffold for bone 
tissue engineering or bone in vitro modelling due to its 3D porous structure and its natural biochemical component arrangement, providing osteoinductive properties that are not fully resembled by synthetic polymers or hydrogels (Nyberg et al., 2017). However, the current challenge of working with decellularized matrices and their translation to clinics is to balance the decellularization methods in order to maintain the specific epitopes that will have a positive impact on cell functions but eliminate any component that could cause an immunogenic response (Gilpin and Yang, 2017; Keane et al., 2016).

\section{The dynamic dimension}

Biomechanical stimuli caused by physical deformation and fluid shear stress generated by interstitial fluid movement through bone lacunae are recognized as a significant part of in vivo bone remodeling (Carter, 1984; Duncan and Turner, 1995). Therefore, to better reassemble the in vivo counterpart, in vitro models for skeletal progenitors may likewise be integrated in an intrinsic dynamic environment.

\section{Dynamic bioreactors}

Dynamic culture of MSCs has expanded greatly in the last 15 years and dynamic optimized bioreactors are now widely used to provide the technological means to achieve both improved nutrient transportation and mechanical stimulation. A variety of dynamic $3 \mathrm{D}$ bioreactor concepts mimicking the native microenvironment of bone tissues have been developed - e.g., perfusion chambers (Dahlin et al., 2012; Hosseinkhani et al., 2006; Kleinhans et al., 2015; Porter et al., 2005; Yeatts and Fisher, 2010), stirred tanks (Eibes et al., 2010; King and Miller, 2007), rotating wall vessels (Nishi et al., 2013; Song et al., 2008), mechanical loading chambers (Altman et al., 2002; Baker et al., 2011; Pelaez et al., 2012; Sittichockechaiwut et al., 2009), and, more recently, nanovibrational reactors (Tsimbouri et al., 2017). MSCs cultured under those dynamic cultures are subjected to mechanical shear created by fluid flow, which promotes osteogenesis via the ERK1/2 pathway through upregulation of Runx2 (Yeatts et al., 2013) and, therefore, provides the right microenvironmental setup to augment bone formation (David et al., 2007; McCoy and O'Brien, 2010; Stiehler et al., 2009).

\section{Microfluidic chips}

The advances in microfluidic technology brought great progresses in the field of dynamic in vitro models, mainly regarding the spatiotemporal control of gradients and the introduction of individual or combination of factors with low volumes and low cell suspension density requirements (Sart et al., 2016; Sun et al., 2012b; Tatárová et al., 2016). Recently, Marturano-Kruik et al. (2018) have developed a perivascular model containing ECs and MSCs seeded on a bone matrix, forming a bone perivascular nicheon-a-chip, which allows following slow-cycling metastatic cancer cells in a BM niche.

\section{Smart materials}

Meanwhile, advances in the material science field have been made with the development of the socalled 'smart' materials - i.e., biomaterials specifically designed to allow dynamic changes in their structure in response to an external stimulus (Kaliva et al., 2017). These materials can be metals or polymers sensitive either to temperature (Dessì et al., 2013; Roy et al., 2013), pH (Wang et al., 2004), magnetic (Ribeiro et al., 2016) or electrical fields (Balint et al., 2014), light (Muraoka et al., 2009; Zhao, 2012), or lytic-enzymes (Hu et al., 2012; Todd et al., 2007). The concept of a dynamic $4^{\text {th }}$ dimension is also being explored in 3D printing approaches for tissue engineering (reviewed by Gladman et al. , 2016; Khoo et al., 2015). The development of new tailored inks capable of adapting their shape or functionalities to external stimuli will surely be a pivotal milestone in achieving reliable and close to in vivo MSC niche models.

\section{In vivo models}

Animal models are a vital part of MSC biology research and MSC-based therapeutic approaches, enabling investigations at the systemic level in a physiological environment. Nevertheless, the prediction of effectiveness of a therapeutic approach in preclinical models can be highly inaccurate, resulting in hurdles upon translation of results in clinics. This frequent discrepancy happens mainly due to (1) intrinsic divergence of molecular mechanisms between species and the non-human stromal component of the ECM, or (2) anatomic discrepancies particularly in orthopedic applications. These facts, along with high costs of maintenance, need for qualified expertise, limited output analysis, and ethical concerns about animal experimentation are motivating governments and regulatory organizations to limit their use and support the implementation of alternative methods following the 3R's principles - firstly established by Russell in 1959 (Russell et al., 1959). Yet, improvements in modeling the complex bone environment (as discussed in the present review) present promising options to provide tissue grafts for regenerative medicine in large bone fractures and, also, to screen with precision therapeutic agents that may facilitate bone repair.

\section{Final remarks}

In vitro models should not be confined to single stationary conditions; i.e., an individual architecture or a particular chemical functionalization with a specific biological function. Instead, it is desirable that the emerging constructs should comprise complex combinatorial signals with tunable cues, to support stemness maintenance or direct stem cell differentiation with spatiotemporal control. Nevertheless, successes in various aspects of the tissue engineering assure a bright future for the development of models that mimic the relevant properties of naïve tissues. The progressive increase in complexity of in vitro models that is been 
witnessed is surely paving the way towards a better understanding of the detailed biological events involved in tissue homeostasis and related disorders in vivo.

\section{Further perspectives}

The localization, identification, and regenerative potential of MSCs is under controversial discussion in the stem cell community. This is mainly attributed to the lack of distinct surface markers for the identification and prospective isolation of naïve MSC/ tissue-specific progenitor cells in vivo in mouse and human, resulting in inconsistences of the studied cell population, and the restriction of many studies to the assessment of the cell regenerative potential in vitro. The in vitro MSC characterization methods are highly artificial and do not proof the function of MSC/tissue-specific progenitor cells in vivo. Indeed, there is an ambiguous distinction between the physiological function of isolated MSCs in culture and their presumed in vivo counterpart - i.e., MSCs isolated from the BM give rise to all the mesenchymal cell lineages (Pittenger et al., 1999) and even transdifferentiate into cells from the central nervous system (Wislet-Gendebien et al., 2005), the skeletal muscle system (Ferrari et al., 1998), the hepatic system (Lee et al., 2004), and the cardiac system (Toma et al., 2002) when exogenously stimulated; whereas naïve non-stimulated BM-MSCs do not share the same phenotypic plasticity (Bara et al., 2014). In fact, robust in vivo assays of progenitor cells from other tissues, all sharing the in vitro characteristics attributed to MSCs (Dominici et al., 2006), suggest that distinct tissue-specific stem/progenitor cells with distinct regenerative capacity exist throughout the body (Robey, 2017; Sipp et al., 2018), specifically settled in a specific environment which control either the maintenance of their stemness or the orchestration of tissue modulation activities. This, along with the increasing amount of data showing a microenvironmental-dependent behavior of MSCs, as reviewed in the present article, highlights the importance of considering and implementing microenvironmental cues upon assessment of the MSC regenerative potential.

Although substantial advances have already been made in the field, the recapitulation of the complex biological recognition and signaling functions, e.g., between cells and ECM, is still crucial and controlling the dynamics and spatial organization of multiple signals remains a current challenge. Substantial testing and optimization is still required to ensure that the $3 \mathrm{D}$ constructs realistically mimic the native tissue counterparts. Accordingly, despite the unquestionable value of MSCs for clinical applications, comprehensive studies of fundamental mechanisms triggered by microenvironmental cues are critical before moving to regenerative medicine cell therapy applications.

The future holds great potential for 3D/4D models for studying tissue dynamics in health and disease as well as for tissue engineering applications. Progress in engineering, technology, biomaterials, and imaging will surely be at the forefront of the MSC niche model revolution.

\section{Acknowledgements}

This work was supported by the Interdisciplinary Center for Clinical Research (IZKF) at the University of Wuerzburg (Project D-361). The authors have no conflict of interest to declare.

\section{References}

Agarwal S, Loder S, Cholok D, Peterson J, Li J, Fireman D, Breuler C, Hsieh HS, Ranganathan K, Hwang C (2016) Local and circulating endothelial cells undergo endothelial to mesenchymal transition (EndMT) in response to musculoskeletal injury. Sci Rep 6: 32514. DOI: 10.1038/srep32514.

Aguirre A, Planell J, Engel E (2010) Dynamics of bone marrow-derived endothelial progenitor cell/ mesenchymal stem cell interaction in co-culture and its implications in angiogenesis. Biochem Biophys Res Commun 400: 284-291.

Akbarzadeh R, Yousefi AM (2014) Effects of processing parameters in thermally induced phase separation technique on porous architecture of scaffolds for bone tissue engineering. J Biomed Mater Res B 102: 1304-1315.

Al-Soudi A, Kaaij M, Tas S (2017) Endothelial cells: from innocent bystanders to active participants in immune responses. Autoimmun Rev 16: 951-962.

Altman GH, Lu HH, Horan RL, Calabro T, Ryder D, Kaplan DL, Stark P, Martin I, Richmond JC, Vunjak-Novakovic G (2002) Advanced bioreactor with controlled application of multi-dimensional strain for tissue engineering. J Biomech Eng 124: 742749.

Alvarez MB, Xu L, Childress PJ, Maupin KA, Mohamad SF, Chitteti BR, Himes E, Olivos III DJ, Cheng Y-H, Conway SJ (2018) Megakaryocyte and osteoblast interactions modulate bone mass and hematopoiesis. Stem Cells Dev 27: 671-682.

Ambard AJ, Mueninghoff L (2006) Calcium phosphate cement: review of mechanical and biological properties. J Prosthodontics 15: 321-328.

Ambrosi TH, Scialdone A, Graja A, Gohlke S, Jank A-M, Bocian C, Woelk L, Fan H, Logan DW, Schürmann A (2017) Adipocyte accumulation in the bone marrow during obesity and aging impairs stem cell-based hematopoietic and bone regeneration. Cell Stem Cell 20: 771-784. 
Amend SR, Roy S, Brown JS, Pienta KJ (2016) Ecological paradigms to understand the dynamics of metastasis. Cancer Lett 380: 237-242.

Angelos MG, Abrahante JE, Blum RH, Kaufman DS (2018) Single cell resolution of human hematoendothelial cells defines transcriptional signatures of hemogenic endothelium. Stem Cells 36: 206-217.

Baker BM, Chen CS (2012) Deconstructing the third dimension: how 3D culture microenvironments alter cellular cues. J Cell Sci 125(Pt 13): 3015-3024.

Baker BM, Shah RP, Huang AH, Mauck RL (2011) Dynamic tensile loading improves the functional properties of mesenchymal stem cell-laden nanofiberbased fibrocartilage. Tissue Eng Part A 17: 1445-1455.

Baksh D, Yao R, Tuan RS (2007) Comparison of proliferative and multilineage differentiation potential of human mesenchymal stem cells derived from umbilical cord and bone marrow. Stem Cells 25: 1384-1392.

Balint R, Cassidy NJ, Cartmell SH (2014) Conductive polymers: towards a smart biomaterial for tissue engineering. Acta Biomater 10: 2341-2353.

Ball SG, Shuttleworth AC, Kielty CM (2004) Direct cell contact influences bone marrow mesenchymal stem cell fate. Int J Biochem Cell Biol 36: 714-727.

Bara JJ, Richards RG, Alini M, Stoddart MJ (2014) Concise review: bone marrow-derived mesenchymal stem cells change phenotype following in vitro culture: implications for basic research and the clinic. Stem Cells 32: 1713-1723.

Bartosh TJ, Ylöstalo JH, Mohammadipoor A, Bazhanov N, Coble K, Claypool K, Lee RH, Choi H, Prockop DJ (2010) Aggregation of human mesenchymal stromal cells (MSCs) into 3D spheroids enhances their antiinflammatory properties. Proc Natl Acad Sci U S A 107: 13724-13729.

Bason C, Gallorini M, Berardi AC (2018) The Extracellular matrix, growth factors and morphogens in biomaterial design and tissue engineering. In: Extracellular matrix for tissue engineering and biomaterials. Editor Berardi AC, Springer Nature Switzerland AG, pp: 3-26.

Beeton C, Bord S, Ireland D, Compston J (2006) Osteoclast formation and bone resorption are inhibited by megakaryocytes. Bone 39: 985-990.

Bianco P, Robey PG, Simmons PJ (2008) Mesenchymal stem cells: revisiting history, concepts, and assays. Cell Stem Cell 2: 313-319.

Bidarra SJ, Barrias CC, Barbosa MA, Soares R, Amédée J, Granja PL (2011) Phenotypic and proliferative modulation of human mesenchymal stem cells via crosstalk with endothelial cells. Stem Cell Res 7: 186-197.

Bignon A, Chouteau J, Chevalier J, Fantozzi G, Carret J-P, Chavassieux P, Boivin G, Melin M, Hartmann D (2003) Effect of micro-and macroporosity of bone substitutes on their mechanical properties and cellular response. J Mater Sci Mater Med 14: 1089-1097.
Biswas S, Li P, Wu H, Shafiquzzaman M, Murakami S, Schneider MD, Mishina Y, Li B, Li J (2018) BMPRIA is required for osteogenic differentiation and RANKL expression in adult bone marrow mesenchymal stromal cells. Sci Rep 8: 8475. DOI: 10.1038/s41598-018-26820-8.

Böhrnsen F, Schliephake H (2016) Supportive angiogenic and osteogenic differentiation of mesenchymal stromal cells and endothelial cells in monolayer and co-cultures. Int J Oral Sci 8: 223-230.

Bonnans C, Chou J, Werb Z (2014) Remodelling the extracellular matrix in development and disease. Nat Rev Mol Cell Biol 15: 786-801.

Bose S, Vahabzadeh S, Bandyopadhyay A (2013) Bone tissue engineering using $3 \mathrm{D}$ printing. Mater Today 16: 496-504.

Bosnakovski D, Mizuno M, Kim G, Takagi S, Okumura M, Fujinaga T (2006) Chondrogenic differentiation of bovine bone marrow mesenchymal stem cells (MSCs) in different hydrogels: influence of collagen type II extracellular matrix on MSC chondrogenesis. Biotechnol Bioeng 93: 1152-1163.

Bottaro DP1, Liebmann-Vinson A, Heidaran MA (2002) Molecular signaling in bioengineered tissue microenvironments. Ann N Y Acad Sci 961: 143-153.

Boulais PE, Frenette PS (2015) Making sense of hematopoietic stem cell niches. Blood 125: 2621-2629.

Breitbach M, Kimura K, Luis TC, Fuegemann CJ, Woll PS, Hesse M, Facchini R, Rieck S, Jobin K, Reinhardt J (2018) In vivo labeling by CD73 marks multipotent stromal cells and highlights endothelial heterogeneity in the bone marrow niche. Cell Stem Cell 22: 262-276. e267.

Bronckaers A, Hilkens P, Martens W, Gervois P, Ratajczak J, Struys T, Lambrichts I (2014) Mesenchymal stem/stromal cells as a pharmacological and therapeutic approach to accelerate angiogenesis. Pharmacol Ther 143: 181-196.

Caplan AI (1991) Mesenchymal stem cells. J Orth Res 9: 641-650.

Caplan AI (2017) Mesenchymal stem cells: time to change the name! Stem Cells Transl Med 6: 1445-1451.

Cappellen D, Luong-Nguyen N-H, Bongiovanni S, Grenet O, Wanke C, Susa M (2002) Transcriptional program of mouse osteoclast differentiation governed by the macrophage colony-stimulating factor and the ligand for the receptor activator of NFKB. J Biol Chem 277: 21971-21982.

Carlotti F, Zaldumbide A, Loomans CJ, van Rossenberg E, Engelse M, de Koning EJ, Hoeben RC (2010) Isolated human islets contain a distinct population of mesenchymal stem cells. Islets 2: 164173.

Caron MM, Emans PJ, Coolsen MM, Voss L, Surtel DA, Cremers A, van Rhijn LW, Welting TJ (2012) Redifferentiation of dedifferentiated human articular chondrocytes: comparison of 2D and 3D cultures. Osteoarthritis Cartilage 20: 1170-1178.

Carter DR (1984) Mechanical loading histories and cortical bone remodeling. Calcif Tissue Int 36: S19-S24. 
Celil AB, Campbell PG (2005) BMP-2 and insulinlike growth factor-I mediate Osterix (Osx) expression in human mesenchymal stem cells via the MAPK and protein kinase D signaling pathways. J Biol Chem 280: 31353-31359.

Chang J-C, Hsu S-h, Chen DC (2009) The promotion of chondrogenesis in adipose-derived adult stem cells by an RGD-chimeric protein in 3D alginate culture. Biomaterials 30: 6265-6275.

Chan JK, Glass GE, Ersek A, Freidin A, Williams GA, Gowers K, Espirito Santo AI, Jeffery R, Otto WR, Poulsom R, Feldmann M, Rankin SM, Horwood NJ, Nanchahal J (2015) Low-dose TNF augments fracture healing in normal and osteoporotic bone by up-regulating the innate immune response. EMBO Mol Med 7: 547-561.

Chen CS (2008) Mechanotransduction - a field pulling together? J Cell Sci 121: 3285-3292.

Chen P-Y, Qin L, Baeyens N, Li G, Afolabi T, Budatha M, Tellides G, Schwartz MA, Simons M (2015) Endothelial-to-mesenchymal transition drives atherosclerosis progression. J Clin Invest 125: 45144528 .

Chen X, Katakowski M, Li Y, Lu D, Wang L, Zhang L, Chen J, Xu Y, Gautam S, Mahmood A (2002) Human bone marrow stromal cell cultures conditioned by traumatic brain tissue extracts: growth factor production. J Neurosci Res 69: 687-691.

Cheng Q, Li X, Liu J, Ye Q, Chen Y, Tan S, Liu J (2017) Multiple myeloma-derived exosomes regulate the functions of mesenchymal stem cells partially via modulating miR-21 and miR-146a. Stem Cells Int 2017: 9012152. DOI: 10.1155/2017/9012152.

Cho D-I, Kim MR, Jeong H-y, Jeong HC, Jeong MH, Yoon SH, Kim YS, Ahn Y (2014) Mesenchymal stem cells reciprocally regulate the M1/M2 balance in mouse bone marrow-derived macrophages. Exp Mol Med 46: e70. DOI: 10.1038/emm.2013.135.

Chowdhury R, Webber JP, Gurney M, Mason MD, Tabi Z, Clayton A (2015) Cancer exosomes trigger mesenchymal stem cell differentiation into pro-angiogenic and pro-invasive myofibroblasts. Oncotarget 6: 715-731.

Ciovacco WA, Cheng YH, Horowitz MC, Kacena MA (2010) Immature and mature megakaryocytes enhance osteoblast proliferation and inhibit osteoclast formation. J Cell Biochem 109: 774-781.

Cipriani P, Guiducci S, Miniati I, Cinelli M, Urbani S, Marrelli A, Dolo V, Pavan A, Saccardi R, Tyndall A (2007) Impairment of endothelial cell differentiation from bone marrow-derived mesenchymal stem cells: new insight into the pathogenesis of systemic sclerosis. Arthritis Rheumatol 56: 1994-2004.

Civini S, Jin P, Ren J, Sabatino M, Castiello L, Jin J, Wang H, Zhao Y, Marincola F, Stroncek D (2013) Leukemia cells induce changes in human bone marrow stromal cells. J Transl Med 11: 298. DOI: 10.1186/1479-5876-11-298.

Cottrill CP, Archer CW, Wolpert L (1987) Cell sorting and chondrogenic aggregate formation in micromass culture. Dev Biol 122: 503-515.
Cox TR, Erler JT (2011) Remodeling and homeostasis of the extracellular matrix: implications for fibrotic diseases and cancer. Dis Model Mech 4: 165-178.

Crapo PM, Gilbert TW, Badylak SF (2011) An overview of tissue and whole organ decellularization processes. Biomaterials 32: 3233-3243.

Crisan M, Dzierzak E (2016) The many faces of hematopoietic stem cell heterogeneity. Development 143: 4571-4581.

Crisan M, Yap S, Casteilla L, Chen C-W, Corselli M, Park TS, Andriolo G, Sun B, Zheng B, Zhang L, Norotte C, Teng P-N, Traas J, Schugar R, Deasy BM, Badylak S, Bühring H-J, Giacobino J-P, Lazzari L, Huard J, Péault B (2008) A perivascular origin for mesenchymal stem cells in multiple human organs. Cell Stem Cell 3: 301-313.

Csaki C, Matis U, Mobasheri A, Shakibaei M (2009) Co-culture of canine mesenchymal stem cells with primary bone-derived osteoblasts promotes osteogenic differentiation. Histochem Cell Biol 131: 251-266.

Curran JM, Chen R, Hunt JA (2006) The guidance of human mesenchymal stem cell differentiation in vitro by controlled modifications to the cell substrate. Biomaterials 27: 4783-4793.

D'Ippolito G, Diabira S, Howard GA, Roos BA, Schiller PC (2006) Low oxygen tension inhibits osteogenic differentiation and enhances stemness of human MIAMI cells. Bone 39: 513-522.

Dahlin RL, Meretoja VV, Ni M, Kasper FK, Mikos AG (2012) Design of a high-throughput flow perfusion bioreactor system for tissue engineering. Tissue Eng Part C Methods 18: 817-820.

Dalby MJ, Gadegaard N, Tare R, Andar A, Riehle MO, Herzyk P, Wilkinson CD, Oreffo RO (2007) The control of human mesenchymal cell differentiation using nanoscale symmetry and disorder. Nat Mater 6: 997-1003.

Datta N, Holtorf HL, Sikavitsas VI, Jansen JA, Mikos AG (2005) Effect of bone extracellular matrix synthesized in vitro on the osteoblastic differentiation of marrow stromal cells. Biomaterials 26: 971-977.

David V, Martin A, Lafage-Proust M-Hln, Malaval L, Peyroche S, Jones DB, Vico L, Guignandon A (2007) Mechanical loading down-regulates peroxisome proliferator-activated receptor $\gamma$ in bone marrow stromal cells and favors osteoblastogenesis at the expense of adipogenesis. Endocrinology 148: 25532562.

de la Guardia RD, Lopez-Millan B, Lavoie JR, Bueno C, Castaño J, Gómez-Casares M, Vives S, Palomo L, Juan M, Delgado J (2017) Detailed characterization of mesenchymal stem/stromal cells from a large cohort of AML patients demonstrates a definitive link to treatment outcomes. Stem Cell Rep 8: 1573-1586.

De Luca L, Trino S, Laurenzana I, Simeon V, Calice G, Raimondo S, Podestà M, Santodirocco M, Di Mauro L, La Rocca F (2016) MiRNAs and piRNAs from bone marrow mesenchymal stem cell 
extracellular vesicles induce cell survival and inhibit cell differentiation of cord blood hematopoietic stem cells: a new insight in transplantation. Oncotarget 7: 6676-6692.

Deng X, Chen YX, Zhang X, Zhang JP, Yin C, Yue HY, Lin Y, Han ZG, Xie WF (2008) Hepatic stellate cells modulate the differentiation of bone marrow mesenchymal stem cells into hepatocyte-like cells. J Cell Physiol 217: 138-144.

Dessì M, Borzacchiello A, Mohamed TH, AbdelFattah WI, Ambrosio L (2013) Novel biomimetic thermosensitive $\beta$-tricalcium phosphate/chitosanbased hydrogels for bone tissue engineering. J Biomed Mater Res A 101: 2984-2993.

Devignes C-S, Aslan Y, Brenot A, Devillers A, Schepers K, Fabre S, Chou J, Casbon A-J, Werb Z, Provot S (2018) HIF signaling in osteoblast-lineage cells promotes systemic breast cancer growth and metastasis in mice. Proc Natl Acad Sci U S A 115: E992-E1001.

Dhawan A, von Bonin M, Bray LJ, Freudenberg U, Pishali Bejestani E, Werner C, Hofbauer LC, Wobus M, Bornhäuser M (2016) Functional interference in the bone marrow microenvironment by disseminated breast cancer cells. Stem Cells 34: 2224-2235.

Ding L, Morrison SJ (2013) Haematopoietic stem cells and early lymphoid progenitors occupy distinct bone marrow niches. Nature 495: 231-235.

Dominici M, Le Blanc K, Mueller I, SlaperCortenbach I, Marini F, Krause D, Deans R, Keating A, Prockop D, Horwitz E (2006) Minimal criteria for defining multipotent mesenchymal stromal cells. The International Society for Cellular Therapy position statement. Cytotherapy 8: 315-317.

Doron B, Handu M, Kurre P (2018) Concise review: adaptation of the bone marrow stroma in hematopoietic malignancies: current concepts and models. Stem Cells 36: 304-312.

Du P, Suhaeri M, Subbiah R, Van SY, Park J, Kim SH, Park K, Lee K (2016) Elasticity modulation of fibroblast-derived matrix for endothelial cell vascular morphogenesis and mesenchymal stem cell differentiation. Tissue Eng Part A 22: 415-426.

Duncan R, Turner C (1995) Mechanotransduction and the functional response of bone to mechanical strain. Calcif Tissue Int 57: 344-358.

Duttenhoefer F, Lara de Freitas R, Loibl M, Bittermann G, Geoff Richards R, Alini M, Verrier S (2015) Endothelial progenitor cell fraction contained in bone marrow-derived mesenchymal stem cell populations impairs osteogenic differentiation. BioMed Res Int 2015: 659542. DOI: 10.1155/2015/659542.

Duttenhoefer F, Lara de Freitas R, Meury T, Loibl M, Benneker LM, Hermann M, Richards R, Alini M, Verrier S (2013) 3D scaffolds co-seeded with human endothelial progenitor and mesenchymal stem cells: evidence of prevascularisation within 7 days. Eur Cell Mater 26: 64-65.

Eibes G, dos Santos F, Andrade PZ, Boura JS, Abecasis MM, da Silva CL, Cabral JM (2010) Maximizing the ex vivo expansion of human mesenchymal stem cells using a microcarrier-based stirred culture system. J Biotechnol 146: 194-197.

Engler AJ, Sen S, Sweeney HL, Discher DE (2006) Matrix elasticity directs stem cell lineage specification. Cell 126: 677-689.

Erba BG, Gruppi C, Corada M, Pisati F, Rosti V, Villeval J-L, Vannucchi AM, Barosi G, Balduini A, Dejana E (2017) Endothelial-to-mesenchymal transition in bone marrow and spleen of primary myelofibrosis. Am J Pathol 187: 1879-1892.

Fehrer C, Brunauer R, Laschober G, Unterluggauer H, Reitinger S, Kloss F, Gülly C, Gassner R, Lepperdinger G (2007) Reduced oxygen tension attenuates differentiation capacity of human mesenchymal stem cells and prolongs their lifespan. Aging Cell 6: 745-757.

Ferrari G, Angelis D, Coletta M, Paolucci E, Stornaiuolo A, Cossu G, Mavilio F (1998) Muscle regeneration by bone marrow-derived myogenic progenitors. Science 279: 1528-1530.

Fink T, Abildtrup L, Fogd K, Abdallah BM, Kassem M, Ebbesen P, Zachar V (2004) Induction of adipocyte-like phenotype in human mesenchymal stem cells by hypoxia. Stem Cells 22: 1346-1355.

Friedenstein A, Deriglasova U, Kulagina N, Panasuk A, Rudakowa S, Luria E, Ruadkow I (1974) Precursors for fibroblasts in different populations of hematopoietic cells as detected by the in vitro colony assay method. Exp Hematol 2: 83-92.

Fukuchi Y, Nakajima H, Sugiyama D, Hirose I, Kitamura T, Tsuji K (2004) Human placenta-derived cells have mesenchymal stem/progenitor cell potential. Stem Cells 22: 649-658.

Galleu A, Riffo-Vasquez Y, Trento C, Lomas C, Dolcetti L, Cheung TS, von Bonin M, Barbieri L, Halai K, Ward S (2017) Apoptosis in mesenchymal stromal cells induces in vivo recipient-mediated immunomodulation. Sci Transl Med 9. DOI: 10.1126/ scitranslmed.aam7828.

Gamblin A-L, Brennan MA, Renaud A, Yagita H, Lézot F, Heymann D, Trichet V, Layrolle P (2014) Bone tissue formation with human mesenchymal stem cells and biphasic calcium phosphate ceramics: the local implication of osteoclasts and macrophages. Biomaterials 35: 9660-9667.

Garimella R, Kacena MA, Tague SE, Wang J, Horowitz MC, Anderson HC (2007) Expression of bone morphogenetic proteins and their receptors in the bone marrow megakaryocytes of GATA-1low mice: a possible role in osteosclerosis. J Histochem Cytochem 55: 745-752.

Gilpin A, Yang Y (2017) Decellularization strategies for regenerative medicine: from processing techniques to applications. BioMed research international 2017: 9831534. DOI: 10.1155/2017/9831534

Gladman AS, Matsumoto EA, Nuzzo RG, Mahadevan L, Lewis JA (2016) Biomimetic 4D printing. Nat Mater 15: 413-418.

Glueck M, Gardner O, Czekanska E, Alini M, Stoddart MJ, Salzmann GM, Schmal H (2015) Induction of osteogenic differentiation in human 
mesenchymal stem cells by crosstalk with osteoblasts. Biores Open Access 4: 121-130.

Gomariz A, Helbling PM, Isringhausen S, Suessbier U, Becker A, Boss A, Nagasawa T, Paul G, Goksel O, Székely G, Stoma S, Nørrelykke SF, Manz MG, Nombela-Arrieta C (2018) Quantitative spatial analysis of haematopoiesis-regulating stromal cells in the bone marrow microenvironment by 3D microscopy. Nat Commun 9: 2532. DOI: 10.1038/ s41467-018-04770-z.

Gomez Perdiguero E, Klapproth K, Schulz C, Busch K, Azzoni E, Crozet L, Garner H, Trouillet C, de Bruijn MF, Geissmann F, Rodewald HR (2015) Tissue-resident macrophages originate from yolksac-derived erythro-myeloid progenitors. Nature 518: 547-551.

Gong M, Yu B, Wang J, Wang Y, Liu M, Paul C, Millard RW, Xiao D-S, Ashraf M, Xu M (2017) Mesenchymal stem cells release exosomes that transfer miRNAs to endothelial cells and promote angiogenesis. Oncotarget 8: 4 45200-45212.

Gordon JA, Lisle JW, Alman BA, Lian JB (2014) Disruption of crosstalk between mesenchymal stromal and tumor cells in bone marrow as a therapeutic target to prevent metastatic bone disease. J Cell Physiol 229: 1884-1886.

Gronthos S, Mankani M, Brahim J, Robey PG, Shi S (2000) Postnatal human dental pulp stem cells (DPSCs) in vitro and in vivo. Proc Natl Acad Sci U S A 97: 13625-13630.

Guibentif C, Rönn RE, Böiers C, Lang S, Saxena S, Soneji S, Enver T, Karlsson G, Woods N-B (2017) Single-cell analysis identifies distinct stages of human endothelial-to-hematopoietic transition. Cell Rep 19: 10-19.

Guimarães-Camboa N, Cattaneo P, Sun Y, MooreMorris T, Gu Y, Dalton ND, Rockenstein E, Masliah E, Peterson KL, Stallcup WB (2017) Pericytes of multiple organs do not behave as mesenchymal stem cells in vivo. Cell Stem Cell 20: 345-359.

Gurkan UA, El Assal R, Yildiz SE, Sung Y, Trachtenberg AJ, Kuo WP, Demirci U (2014) Engineering anisotropic biomimetic fibrocartilage microenvironment by bioprinting mesenchymal stem cells in nanoliter gel droplets. Mol Pharm 11: 2151-2159.

Hammoud M, Vlaski M, Duchez P, Chevaleyre J, Lafarge X, Boiron JM, Praloran V, Brunet de la Grange P, Ivanovic Z (2012) Combination of low $\mathrm{O} 2$ concentration and mesenchymal stromal cells during culture of cord blood CD34+ cells improves the maintenance and proliferative capacity of hematopoietic stem cells. J Cell Physiol 227: 27502758.

Hashimoto K, Ochi H, Sunamura S, Kosaka N, Mabuchi Y, Fukuda T, Yao K, Kanda H, Ae K, Okawa A (2018) Cancer-secreted hsa-miR-940 induces an osteoblastic phenotype in the bone metastatic microenvironment via targeting ARHGAP1 and FAM134A. Proc Natl Acad Sci U S A 115: 2204-2209.
Hass R, Kasper C, Böhm S, Jacobs R (2011) Different populations and sources of human mesenchymal stem cells (MSC): a comparison of adult and neonatal tissue-derived MSC. Cell Commun Signal 9: 12. DOI: 10.1186/1478-811X-9-12.

Henriksen K, Sørensen MG, Nielsen RH, Gram J, Schaller S, Dziegiel MH, Everts V, Bollerslev J, Karsdal MA (2006) Degradation of the organic phase of bone by osteoclasts: a secondary role for lysosomal acidification. J Bone Miner Res 21: 58-66.

Hermida-Gómez T, Fuentes-Boquete I, GimenoLongas MJ, Muiños-López E, Díaz-Prado S, BLANCO FJ (2011) Quantification of cells expressing mesenchymal stem cell markers in healthy and osteoarthritic synovial membranes. J Rheumatol 38: 339-349.

Herrmann M, Binder A, Menzel U, Zeiter S, Alini M, Verrier S (2014) CD34/CD133 enriched bone marrow progenitor cells promote neovascularization of tissue engineered constructs in vivo. Stem Cell Res 13: $465-477$.

Herrmann M, Jakob F (2019) Bone marrow niches for skeletal progenitor cells and their inhabitants in health and disease. Curr Stem Cell Res Ther. DOI: 10 .2174/1574888X14666190123161447.

Hing K, Annaz B, Saeed S, Revell P, Buckland T (2005) Microporosity enhances bioactivity of synthetic bone graft substitutes. J Mater Sci Mater Med 16: 467-475.

Hoch AI, Mittal V, Mitra D, Vollmer N, Zikry CA, Leach JK (2016) Cell-secreted matrices perpetuate the bone-forming phenotype of differentiated mesenchymal stem cells. Biomaterials 74: 178-187.

Horwitz E, Le Blanc K, Dominici M, Mueller I, Slaper-Cortenbach I, Marini FC, Deans R, Krause D, Keating A (2005) Clarification of the nomenclature for MSC: The International Society for Cellular Therapy position statement. Cytotherapy 7: 393-395.

Hoshiba T, Lu H, Kawazoe N, Chen G (2010) Decellularized matrices for tissue engineering. Expert Opin Biol Ther 10: 1717-1728.

Hosseinkhani H, Hosseinkhani M, Tian F, Kobayashi H, Tabata Y (2006) Ectopic bone formation in collagen sponge self-assembled peptide-amphiphile nanofibers hybrid scaffold in a perfusion culture bioreactor. Biomaterials 27: 5089-5098.

Hu J, Zhang G, Liu S (2012) Enzyme-responsive polymeric assemblies, nanoparticles and hydrogels. Chem Soc Rev 41: 5933-5949.

Hu X, Yu SP, Fraser JL, Lu Z, Ogle ME, Wang J-A, Wei L (2008) Transplantation of hypoxiapreconditioned mesenchymal stem cells improves infarcted heart function via enhanced survival of implanted cells and angiogenesis. J Thorac Cardiovasc Surg 135: 799-808.

Huebsch N, Lippens E, Lee K, Mehta M, Koshy ST, Darnell MC, Desai R, Madl CM, Xu M, Zhao X (2015) Matrix elasticity of void-forming hydrogels controls transplanted stem cell-mediated bone formation. Nat Mater 14: 1269-1277. 
Indrawattana N, Chen G, Tadokoro M, Shann LH, Ohgushi H, Tateishi T, Tanaka J, Bunyaratvej A (2004) Growth factor combination for chondrogenic induction from human mesenchymal stem cell. Biochem Biophys Res Commun 320: 914-919.

Itkin T, Gur-Cohen S, Spencer JA, Schajnovitz A, Ramasamy SK, Kusumbe AP, Ledergor G, Jung Y, Milo I, Poulos MG (2016) Distinct bone marrow blood vessels differentially regulate haematopoiesis. Nature 532: 323-328.

Jalali S, del Pozo MA, Chen K-D, Miao H, Li Y-S, Schwartz MA, Shyy JY-J, Chien S (2001) Integrinmediated mechanotransduction requires its dynamic interaction with specific extracellular matrix (ECM) ligands. Proc Natl Acad Sci U S A 98: 1042-1046.

Johnstone B, Hering TM, Caplan AI, Goldberg VM, Yoo JU (1998) In vitro chondrogenesis of bone marrow-derived mesenchymal progenitor cells. Exp Cell Res 238: 265-272.

Jung $\mathrm{Y}$, Song J, Shiozawa Y, Wang J, Wang Z, Williams B, Havens A, Schneider A, Ge C, Franceschi RT (2008) Hematopoietic stem cells regulate mesenchymal stromal cell induction into osteoblasts thereby participating in the formation of the stem cell niche. Stem Cells 26: 2042-2051.

Kacena MA, Gundberg CM, Horowitz MC (2006) A reciprocal regulatory interaction between megakaryocytes, bone cells, and hematopoietic stem cells. Bone 39: 978-984.

Kaliva M, Chatzinikolaidou M, Vamvakaki M (2017) Applications of smart multifunctional tissue engineering scaffolds. In: Smart materials for tissue engineering. Editor Wang Q, Royal Society of Chemistry, pp: 1-38.

Kanichai M, Ferguson D, Prendergast PJ, Campbell VA (2008) Hypoxia promotes chondrogenesis in rat mesenchymal stem cells: a role for AKT and hypoxiainducible factor (HIF)-1 $\alpha$. J Cell Physiol 216: 708-715.

Keane T, Saldin L, BadylakS(2016) Decellularization of mammalian tissues: preparing extracellular matrix bioscaffolds. In: Characterisation and design of tissue scaffolds. Elsevier, pp: 75-103.

Khoo ZX, Teoh JEM, Liu Y, Chua CK, Yang S, An J, Leong KF, Yeong WY (2015) 3D printing of smart materials: A review on recent progresses in $4 \mathrm{D}$ printing. Virtual Phys Prototyp 10: 103-122.

Kim JH, Kim K, Kim I, Seong S, Kim N (2018) c-Src-dependent and -independent functions of Matk in osteoclasts and osteoblasts. J Immunol 200: 24552463.

Kim JH, Kim K, Youn BU, Lee J, Kim I, Shin H-I, Akiyama H, Choi Y, Kim N (2014) Kruppel-like factor 4 attenuates osteoblast formation, function, and cross talk with osteoclasts. J Cell Biol 204: 1063-1074.

King JA, Miller WM (2007) Bioreactor development for stem cell expansion and controlled differentiation. Curr Opin Chem Biol 11: 394-398.

Klein-Nulend J, Bakker AD, Bacabac RG, Vatsa A, Weinbaum S (2013) Mechanosensation and transduction in osteocytes. Bone 54: 182-190.
Kleinhans C, Mohan RR, Vacun G, Schwarz T, Haller B, Sun Y, Kahlig A, Kluger P, Finne-Wistrand A, Walles H (2015) A perfusion bioreactor system efficiently generates cell-loaded bone substitute materials for addressing critical size bone defects. Biotechnol J 10: 1727-1738.

Kratchmarova I, Blagoev B, Haack-Sorensen M, Kassem M, Mann M (2005) Mechanism of divergent growth factor effects in mesenchymal stem cell differentiation. Science 308: 1472-1477.

Kuboki T, Kidoaki S (2016)Fabrication of elasticitytunable gelatinous gel for mesenchymal stem cell culture. In: Mesenchymal stem cells: methods and protocols. Humana Press, New York, NY, pp 425-441.

Kusumbe AP, Ramasamy SK, Itkin T, Mäe MA, Langen UH, Betsholtz C, Lapidot T, Adams RH (2016) Age-dependent modulation of vascular niches for haematopoietic stem cells. Nature 532: 380-384.

Langen UH, Pitulescu ME, Kim JM, EnriquezGasca R, Sivaraj KK, Kusumbe AP, Singh A, Di Russo J, Bixel MG, Zhou B, Sorokin L, Vaquerizas JM, Adams RH (2017) Cell-matrix signals specify bone endothelial cells during developmental osteogenesis. Nat Cell Biol 19 :189-201.

Lee J, Li M, Milwid J, Dunham J, Vinegoni C, Gorbatov R, Iwamoto Y, Wang F, Shen K, Hatfield K (2012) Implantable microenvironments to attract hematopoietic stem/cancer cells. Proc Natl Acad Sci U S A 109: 19638-19643.

Lee KD, Kuo TKC, Whang-Peng J, Chung YF, Lin CT, Chou SH, Chen JR, Chen YP, Lee OKS (2004) In vitro hepatic differentiation of human mesenchymal stem cells. Hepatology 40: 1275-1284.

Levato R, Visser J, Planell JA, Engel E, Malda J, Mateos-Timoneda MA (2014) Biofabrication of tissue constructs by 3D bioprinting of cell-laden microcarriers. Biofabrication 6: 035020. DOI: 10.1088/1758-5082/6/3/035020.

Li J-w, Guo X-1, He C-1, Tuo Y-h, Wang Z, Wen $\mathrm{J}$, Jin D (2011) In vitro chondrogenesis of the goat bone marrow mesenchymal stem cells directed by chondrocytes in monolayer and 3-dimetional indirect co-culture system. Chin Med J 124: 3080-3086.

Li L, Xie T (2005) Stem cell niche: structure and function. Annu Rev Cell Dev Biol 21: 605-631.

Lin L, Du L, Cao K, Huang Y, Yu P, Zhang L, Li F, Wang Y, Shi Y (2016) Tumour cell-derived exosomes endow mesenchymal stromal cells with tumourpromotion capabilities. Oncogene 35: 6038-6042.

Lin R-Z, Moreno-Luna R, Li D, Jaminet S-C, Greene AK, Melero-Martin JM (2014) Human endothelial colony-forming cells serve as trophic mediators for mesenchymal stem cell engraftment via paracrine signaling. Proc Natl Acad Sci U S A 111: 10137-10142.

Liu H, Liu S, Li Y, Wang X, Xue W, Ge G, Luo $X$ (2012) The role of SDF-1-CXCR4/CXCR7 axis in the therapeutic effects of hypoxia-preconditioned mesenchymal stem cells for renal ischemia/ reperfusion injury. PLoS One 7: e34608. DOI: 10.1371/ journal.pone.0034608. 
Loh QL, Choong C (2013) Three-dimensional scaffolds for tissue engineering applications: role of porosity and pore size. Tissue Eng Part B Rev 19: 485-502.

Loibl M, Binder A, Herrmann M, Duttenhoefer F, Richards RG, Nerlich M, Alini M, Verrier S (2014) Direct cell-cell contact between mesenchymal stem cells and endothelial progenitor cells induces a pericyte-like phenotype in vitro. BioMed Res Int 2014: 395781. DOI: 10.1155/2014/395781.

Lu P, Weaver VM, Werb Z (2012) The extracellular matrix: a dynamic niche in cancer progression. J Cell Biol 196: 395-406.

Lund T, Kramer A, Taisto M, Blake A, Lehrke M (2017) Decellularized bone marrow reveals a novel niche protein that modulate adhesion. Exp Hematol 53: S81. DOI: 10.1016/j.exphem.2017.06.177.

Luo J, Tang M, Huang J, He B-C, Gao J-L, Chen L, Zuo G-W, Zhang W, Luo Q, Shi Q (2010) TGF $\beta /$ BMP type I receptors ALK1 and ALK2 are essential for BMP9-induced osteogenic signaling in mesenchymal stem cells. J Biol Chem 285: 29588-29598.

Luo Q, Song G, Song Y, Xu B, Qin J, Shi Y (2009) Indirect co-culture with tenocytes promotes proliferation and mRNA expression of tendon/ ligament related genes in rat bone marrow mesenchymal stem cells. Cytotechnology 61: 1-10.

Lutolf M, Hubbell J (2005) Synthetic biomaterials as instructive extracellular microenvironments for morphogenesis in tissue engineering. Nat Biotechnol 23: 47-55.

Lutolf M, Lauer-Fields J, Schmoekel H, Metters AT, Weber F, Fields G, Hubbell JA (2003) Synthetic matrix metalloproteinase-sensitive hydrogels for the conduction of tissue regeneration: engineering cell-invasion characteristics. Proc Natl Acad Sci U S A 100: 5413-5418.

Lymperi S, Ersek A, Ferraro F, Dazzi F, Horwood NJ (2011) Inhibition of osteoclast function reduces hematopoietic stem cell numbers in vivo. Blood 117: 1540-1549.

Madl CM, Mehta M, Duda GN, Heilshorn SC, Mooney DJ (2014) Presentation of BMP-2 mimicking peptides in 3D hydrogels directs cell fate commitment in osteoblasts and mesenchymal stem cells. Biomacromolecules 15: 445-455.

Mahrouf-Yorgov M, Augeul L, Da Silva CC, Jourdan M, Rigolet M, Manin S, Ferrera R, Ovize M, Henry A, Guguin A (2017) Mesenchymal stem cells sense mitochondria released from damaged cells as danger signals to activate their rescue properties. Cell Death Differ 24: 1224-1238.

Maia FR, Lourenco AH, Granja PL, Goncalves RM, Barrias CC (2014) Effect of cell density on mesenchymal stem cells aggregation in RGD-alginate 3D matrices under osteoinductive conditions. Macromol Biosci 14: 759-771.

Malda J, Visser J, Melchels FP, Jüngst T, Hennink WE, Dhert WJ, Groll J, Hutmacher DW (2013) 25th anniversary article: engineering hydrogels for biofabrication. Adv Mater 25: 5011-5028.
Maldonado M, Nam J (2013) The role of changes in extracellular matrix of cartilage in the presence of inflammation on the pathology of osteoarthritis. BioMed Res Int 2013: 284873. DOI: 10.1155/2013/284873.

Manduca P, Castagnino A, Lombardini D, Marchisio S, Soldano S, Ulivi V, Zanotti S, Garbi C, Ferrari N, Palmieri D (2009) Role of MT1-MMP in the osteogenic differentiation. Bone 44: 251-265.

Mansour A, Abou-Ezzi G, Sitnicka E, Jacobsen SEW, Wakkach A, Blin-Wakkach C (2012) Osteoclasts promote the formation of hematopoietic stem cell niches in the bone marrow. J Exp Med 209: 537-549.

Marfy-Smith SJ, Clarkin CE (2017) Are mesenchymal stem cells so bloody great after all? Stem Cells Transl Med 6: 3-6.

Marturano-Kruik A, Nava MM, Yeager K, Chramiec A, Hao L, Robinson S, Guo E, Raimondi MT, Vunjak-Novakovic G (2018) Human bone perivascular niche-on-a-chip for studying metastatic colonization. Proc Natl Acad Sci U S A 115: 1256-1261.

Matsumoto T, Takami T, Sakaida I (2016) Cell transplantation as a non-invasive strategy for treating liver fibrosis. Expert Rev Gastroenterol Hepatol 10: 639-648.

McCoy RJ, O'Brien FJ (2010) Influence of shear stress in perfusion bioreactor cultures for the development of three-dimensional bone tissue constructs: a review. Tissue Eng Part B Rev 16: 587601.

McMurray RJ (2011) Nanoscale surfaces for the long-term maintenance of mesenchymal stem cell phenotype and multipotency. Nat Mater 10: 637-644.

McNamara LE, McMurray RJ, Biggs MJ, Kantawong F, Oreffo RO, Dalby MJ (2010) Nanotopographical control of stem cell differentiation. J Tissue Eng 2010: 120623.DOI: 10.4061/2010/120623.

Medici D, Olsen BR (2012) The role of endothelialmesenchymal transition in heterotopic ossification. J Bone Miner Res 27: 1619-1622.

Méndez-Ferrer S, Michurina TV, Ferraro F, Mazloom AR, MacArthur BD, Lira SA, Scadden DT, Ma'ayan A, Enikolopov GN, Frenette PS (2010) Mesenchymal and haematopoietic stem cells form a unique bone marrow niche. Nature 466: 829-834.

Menon LG, Picinich S, Koneru R, Gao H, Lin SY, Koneru M, Mayer-Kuckuk P, Glod J, Banerjee D (2007) Differential gene expression associated with migration of mesenchymal stem cells to conditioned medium from tumor cells or bone marrow cells. Stem Cells 25: 520-528.

Muraoka T, Koh CY, Cui H, Stupp SI (2009) Lighttriggered bioactivity in three dimensions. Angew Chem 121: 6060-6063.

Nakamura Y, Arai F, Iwasaki H, Hosokawa K, Kobayashi I, Gomei Y, Matsumoto Y, Yoshihara $H$, Suda T (2010) Isolation and characterization of endosteal niche cell populations that regulate hematopoietic stem cells. Blood 116: 1422-1432.

Nicolaidou V, Wong MM, Redpath AN, Ersek A, Baban DF, Williams LM, Cope AP, Horwood NJ 
(2012) Monocytes induce STAT3 activation in human mesenchymal stem cells to promote osteoblast formation. PLoS One 7: e39871. DOI: 10.1371/journal. pone.0039871.

Nishi M, Matsumoto R, Dong J, Uemura T (2013) Engineered bone tissue associated with vascularization utilizing a rotating wall vessel bioreactor. J Biomed Mater Res A 101: 421-427.

Nyberg E, Rindone A, Dorafshar A, Grayson WL (2017) Comparison of 3D-printed poly- $\varepsilon$-caprolactone scaffolds functionalized with tricalcium phosphate, hydroxyapatite, bio-oss, or decellularized bone matrix. Tissue Eng Part A 23: 503-514.

O'brien FJ (2011) Biomaterials \& scaffolds for tissue engineering. Mater Today 14: 88-95.

Oh S, Brammer KS, Li YJ, Teng D, Engler AJ, Chien S, Jin S (2009) Stem cell fate dictated solely by altered nanotube dimension. Proc Natl Acad Sci U S A 106: 2130-2135.

Ono M, Kosaka N, Tominaga N, Yoshioka Y, Takeshita F, Takahashi R-u, Yoshida M, Tsuda H, Tamura K, Ochiya T (2014) Exosomes from bone marrow mesenchymal stem cells contain a microRNA that promotes dormancy in metastatic breast cancer cells. Sci Signal 7: ra63. DOI: 10.1126/ scisignal.2005231.

Oshita K, Yamaoka K, Udagawa N, Fukuyo S, Sonomoto K, Maeshima K, Kurihara R, Nakano K, Saito K, Okada Y (2011) Human mesenchymal stem cells inhibit osteoclastogenesis through osteoprotegerin production. Arthritis Rheumatol 63: 1658-1667.

Otsu K, Das S, Houser SD, Quadri SK, Bhattacharya S, Bhattacharya J (2009) Concentration-dependent inhibition of angiogenesis by mesenchymal stem cells. Blood 113: 4197-4205.

Owen M (1988) Marrow stromal stem cells. J Cell Sci 1988: 63-76.

Park JC, Kim JM, Jung IH, Kim JC, Choi SH, Cho KS, Kim CS (2011) Isolation and characterization of human periodontal ligament (PDL) stem cells (PDLSCs) from the inflamed PDL tissue: in vitro and in vivo evaluations. J Clin Periodontol 38: 721-731.

Park K-H, Kim H, Moon S, Na K (2009) Bone morphogenic protein-2 (BMP-2) loaded nanoparticles mixed with human mesenchymal stem cell in fibrin hydrogel for bone tissue engineering. J Biosci Bioeng 108: $530-537$.

Park SJ, Lee E-J, Kim Y-H, Shin J-E, Kang Y-H (2014) Inhibitory effects of gossypin on RANKLinduced osteoclast differentiation and bone resorption in murine macrophages (LB364). FASEB J 28: LB364.

Peired AJ, Sisti A, Romagnani P (2016) Mesenchymal stem cell-based therapy for kidney disease: a review of clinical evidence. Stem Cells Int 2016: 4798639.

Pek YS, Wan AC, Ying JY (2010) The effect of matrix stiffness on mesenchymal stem cell differentiation in a 3D thixotropic gel. Biomaterials 31: 385-391.

Pelaez D, Arita N, Cheung HS (2012) Extracellular signal-regulated kinase (ERK) dictates osteogenic and/or chondrogenic lineage commitment of mesenchymal stem cells under dynamic compression. Biochem Biophys Res Commun 417: 1286-1291.

Pereira RF, O'Hara MD, Laptev AV, Halford KW, Pollard MD, Class R, Simon D, Livezey K, Prockop DJ (1998) Marrow stromal cells as a source of progenitor cells for nonhematopoietic tissues in transgenic mice with a phenotype of osteogenesis imperfecta. Proc Natl Acad Sci U S A 95: 1142-1147.

Phillippi JA, Miller E, Weiss L, Huard J, Waggoner A, Campbell P (2008) Microenvironments engineered by inkjet bioprinting spatially direct adult stem cells toward muscle-and bone-like subpopulations. Stem Cells 26: 127-134.

Phillips JE, Petrie TA, Creighton FP, García AJ (2010) Human mesenchymal stem cell differentiation on self-assembled monolayers presenting different surface chemistries. Acta Biomater 6: 12-20.

Phinney DG, Prockop DJ (2007) Concise review: mesenchymal stem/multipotent stromal cells: the state of transdifferentiation and modes of tissue repair - current views. Stem Cells 25: 2896-2902.

Pina S, Oliveira JM, Reis RL (2016) Biomimetic strategies to engineer mineralized human tissues. In: Handbook of bioceramics and biocomposites (Antoniac IV, ed), Springer International Publishing, Cham, pp 503-519.

Pittenger MF, Mackay AM, Beck SC, Jaiswal RK, Douglas R, Mosca JD, Moorman MA, Simonetti DW, Craig S, Marshak DR (1999) Multilineage potential of adult human mesenchymal stem cells. Science 284: 143-147.

Plotnikov E, Khryapenkova T, Vasileva A, Marey M, Galkina S, Isaev N, Sheval E, Polyakov V, Sukhikh G, Zorov D (2008) Cell-to-cell cross-talk between mesenchymal stem cells and cardiomyocytes in coculture. J Cell Mol Med 12: 1622-1631.

Porter B, Zauel R, Stockman H, Guldberg R, Fyhrie D (2005) 3-D computational modeling of media flow through scaffolds in a perfusion bioreactor. J Biomech 38: 543-549.

Potapova IA, Brink PR, Cohen IS, Doronin SV (2008) Culturing of human mesenchymal stem cells as three-dimensional aggregates induces functional expression of CXCR4 that regulates adhesion to endothelial cells. J Biol Chem 283: 13100-13107.

Prager P, Kunz M, Ebert R, Klein-Hitpass L, Sieker J, Barthel T, Jakob F, Konrads C, Steinert A (2018) Mesenchymal stem cells isolated from the anterior cruciate ligament: characterization and comparison of cells from young and old donors. Knee Surg Relat Res 30: 193-205.

Prockop DJ, Oh JY (2012) Mesenchymal stem/stromal cells (MSCs): role as guardians of inflammation. Mol Ther 20: 14-20.

Qian L, Saltzman WM (2004) Improving the expansion and neuronal differentiation of mesenchymal stem cells through culture surface modification. Biomaterials 25: 1331-1337.

Qin Y, Zhang C (2017) Endothelial progenitor cell-derived extracellular vesicle-meditated cell-to-cell 
communication regulates the proliferation and osteoblastic differentiation of bone mesenchymal stromal cells. Mol Med Report 16: 7018-7024.

Raic A, Rödling L, Kalbacher H, Lee-Thedieck C (2014) Biomimetic macroporous PEG hydrogels as $3 \mathrm{D}$ scaffolds for the multiplication of human hematopoietic stem and progenitor cells. Biomaterials 35: 929-940.

Raggatt LJ, Wullschleger ME, Alexander KA, Wu AC, Millard SM, Kaur S, Maugham ML, Gregory LS, Steck R, Pettit AR (2014) Fracture healing via periosteal callus formation requires macrophages for both initiation and progression of early endochondral ossification. Am J Pathol 184: 3192-3204.

Raicevic G, Najar M, Stamatopoulos B, De Bruyn C, Meuleman N, Bron D, Toungouz M, Lagneaux L (2011) The source of human mesenchymal stromal cells influences their TLR profile as well as their functional properties. Cell Immunol 270: 207-216.

Ramasamy SK, Kusumbe AP, Itkin T, GurCohen S, Lapidot T, Adams RH (2016) Regulation of hematopoiesis and osteogenesis by blood vesselderived signals. Annu Rev Cell Dev Biol 32: 649-675.

Ranade SS, Syeda R, Patapoutian A (2015) Mechanically activated ion channels. Neuron 87: 1162-1179.

Rao PS, Martinez JS, Keller III TC (2014) Decellularized ECM effects on human mesenchymal stem cell stemness and differentiation. Differentiation 88: 131-143.

Ribeiro C, Correia V, Martins P, Gama F, Lanceros-Mendez S (2016) Proving the suitability of magnetoelectric stimuli for tissue engineering applications. Colloids Surf B Biointerfaces 140: 430436.

Robey P (2017) "Mesenchymal stem cells": fact or fiction, and implications in their therapeutic use. F1000 Res 6. pii: F1000 Faculty Rev-524. DOI: 10.12688/f1000research.10955.1.

Robins JC, Akeno N, Mukherjee A, Dalal RR, Aronow BJ, Koopman P, Clemens TL (2005) Hypoxia induces chondrocyte-specific gene expression in mesenchymal cells in association with transcriptional activation of Sox9. Bone 37: 313-322.

Roccaro AM, Sacco A, Purschke WG, Moschetta M, Buchner K, Maasch C, Zboralski D, Zöllner S, Vonhoff S, Mishima Y (2014) SDF-1 inhibition targets the bone marrow niche for cancer therapy. Cell Rep 9: $118-128$.

Rojo L, Gharibi B, McLister R, Meenan BJ, Deb $S$ (2016) Self-assembled monolayers of alendronate on Ti6Al4V alloy surfaces enhance osteogenesis in mesenchymal stem cells. Sci Rep 6: 30548. DOI: 10.1038/srep30548.

Rosenkranz K, Kumbruch S, Lebermann K, Marschner K, Jensen A, Dermietzel R, Meier C (2010) The chemokine SDF-1/CXCL12 contributes to the 'homing' of umbilical cord blood cells to a hypoxicischemic lesion in the rat brain. J Neurosci Res 88: 1223-1233.
Rossnagl S, Ghura H, Groth C, Altrock E, Jakob F, Schott S, Wimberger P, Link T, Kuhlmann JD, Stenzl A (2018) A subpopulation of stromal cells controls cancer cell homing to the bone marrow. Cancer Res 78: 129-142.

Roy D, Brooks WL, Sumerlin BS (2013) New directions in thermoresponsive polymers. Chem Soc Rev 42: 7214-7243.

Rozario T, DeSimone DW (2010) The extracellular matrix in development and morphogenesis: a dynamic view. Dev Biol 341: 126-140.

Russell WMS, Burch RL, Hume CW (1959) The principles of humane experimental technique. Johns Hopkins University, Baltimore, MD, USA.

Sacchetti B, Funari A, Michienzi S, Di Cesare S, Piersanti S, Saggio I, Tagliafico E, Ferrari S, Robey PG, Riminucci M (2007) Self-renewing osteoprogenitors in bone marrow sinusoids can organize a hematopoietic microenvironment. Cell 131: 324-336.

Sacchetti B, Funari A, Remoli C, Giannicola G, Kogler G, Liedtke S, Cossu G, Serafini M, Sampaolesi M, Tagliafico E (2016) No identical "mesenchymal stem cells" at different times and sites: human committed progenitors of distinct origin and differentiation potential are incorporated as adventitial cells in microvessels. Stem Cell Rep 6: 897-913.

Saleh F, Whyte M, Genever P (2011) Effects of endothelial cells on human mesenchymal stem cell activity in a three-dimensional in vitro model. Eur Cell Mater 22: 242-257.

Sart S, Agathos SN, Li Y, Ma T (2016) Regulation of mesenchymal stem cell 3D microenvironment: from macro to microfluidic bioreactors. Biotechnol J 11: 43-57.

Sarugaser R, Lickorish D, Baksh D, Hosseini MM, Davies JE (2005) Human umbilical cord perivascular (HUCPV) cells: a source of mesenchymal progenitors. Stem Cells 23: 220-229.

Saxena P, Heng BC, Bai P, Folcher M, Zulewski H, Fussenegger M (2016) A programmable synthetic lineage-control network that differentiates human IPSCs into glucose-sensitive insulin-secreting betalike cells. Nat Commun 7: 11247. DOI: 10.1038/ ncomms11247.

Scadden DT (2006) The stem-cell niche as an entity of action. Nature 441: 1075-1079.

Schneider PR, Buhrmann C, Mobasheri A, Matis U, Shakibaei M (2011) Three-dimensional highdensity co-culture with primary tenocytes induces tenogenic differentiation in mesenchymal stem cells. J Orth Res 29: 1351-1360.

Schofield R (1978) The relationship between the spleen colony-forming cell and the haemopoietic stem cell. Blood Cells 4: 7-25.

Schroeder T, Geyh S, Germing U, Haas R (2016) Mesenchymal stromal cells in myeloid malignancies. Blood Res 51: 225-232.

Schultz GS, Wysocki A (2009) Interactions between extracellular matrix and growth factors in wound healing. Wound Repair Regen 17: 153-162. 
Schwab K, Hutchinson P, Gargett C (2008) Identification of surface markers for prospective isolation of human endometrial stromal colonyforming cells. Hum Reprod 23: 934-943.

Schwartz MA (2010) Integrins and extracellular matrix in mechanotransduction. Cold Spring Harb Perspect Biol 2: a005066. DOI: 10.1101/cshperspect. a005066.

Seib FP, Prewitz M, Werner C, Bornhäuser M (2009) Matrix elasticity regulates the secretory profile of human bone marrow-derived multipotent mesenchymal stromal cells (MSCs). Biochem Biophys Res Commun 389: 663-667.

Seo B-M, Miura M, Gronthos S, Bartold PM, Batouli S, Brahim J, Young M, Robey PG, Wang CY, Shi S (2004) Investigation of multipotent postnatal stem cells from human periodontal ligament. Lancet 364: 149-155.

Shao B, Liao L, Yu Y, Shuai Y, Su X, Jing H, Yang D, Jin $Y$ (2015) Estrogen preserves Fas ligand levels by inhibiting microRNA-181a in bone marrow-derived mesenchymal stem cells to maintain bone remodeling balance. FASEB J 29: 3935-3944.

Sharaf-Eldin WE, Abu-Shahba N, Mahmoud M, El-Badri N (2016) The modulatory effects of mesenchymal stem cells on osteoclastogenesis. Stem Cells Int 2016: 1908365. DOI: 10.1155/2016/1908365.

Shiozawa Y, Eber MR, Berry JE, Taichman RS (2015) Bone marrow as a metastatic niche for disseminated tumor cells from solid tumors. Bonekey Rep 4: 689. DOI: 10.1038/bonekey.2015.57.

Siciliano C, Chimenti I, Ibrahim M, Napoletano C, Mangino G, Scaletta G, Zoccai GB, Rendina EA, Calogero A, Frati G (2015) Cardiosphere conditioned media influence the plasticity of human mediastinal adipose tissue-derived mesenchymal stem cells. Cell Transplant 24: 2307-2322.

Simonson OE, Mougiakakos D, Heldring N, Bassi G, Johansson HJ, Dalén M, Jitschin R, Rodin S, Corbascio M, El Andaloussi S (2015) In vivo effects of mesenchymal stromal cells in two patients with severe acute respiratory distress syndrome. Stem Cells Transl Med 4: 1199-1213.

Sipp D, Robey PG, Turner L (2018) Clear up this stem-cell mess. Nature 561: 455-457.

Sittichockechaiwut A, Scutt AM, Ryan AJ, Bonewald LF, Reilly GC (2009) Use of rapidly mineralising osteoblasts and short periods of mechanical loading to accelerate matrix maturation in 3D scaffolds. Bone 44: 822-829.

Song K, Liu T, Cui Z, Li X, Ma X (2008) Threedimensional fabrication of engineered bone with human bio-derived bone scaffolds in a rotating wall vessel bioreactor. J Biomed Mater Res A 86: 323-332.

Squillaro T, Peluso G, Galderisi U (2016) Clinical trials with mesenchymal stem cells: an update. Cell Transplant 25: 829-848.

Stanciuc A-M, Flamant Q, Biotteau-Deheuvels K, Stoddart MJ, Anglada M, Porporati AA, Kuntz M, Gremillard L, Alini M, Peroglio M (2018) Human primary osteoblast behaviour on microrough zirconia-toughened alumina and on selectively etched microrough zirconia-toughened alumina. J Eur Ceram Soc 38: 927-937.

Steinert AF, Kunz M, Prager P, Göbel S, KleinHitpass L, Ebert R, Nöth U, Jakob F, Gohlke F (2015) Characterization of bursa subacromialis-derived mesenchymal stem cells. Stem Cell Res Ther 6: 114. DOI: 10.1186/s13287-015-0104-3.

Stiehler M, Bünger C, Baatrup A, Lind M, Kassem M, Mygind T (2009) Effect of dynamic 3-D culture on proliferation, distribution, and osteogenic differentiation of human mesenchymal stem cells. J Biomed Mater Res A 89: 96-107.

Strassburg S, Richardson SM, Freemont AJ, Hoyland JA (2010) Co-culture induces mesenchymal stem cell differentiation and modulation of the degenerate human nucleus pulposus cell phenotype. Regen Med 5: 701-711.

Sun Y, Cai J, Yu S, Chen S, Li F, Fan C (2016) MiR630 inhibits endothelial-mesenchymal transition by targeting slug in traumatic heterotopic ossification. Sci Rep 6: 22729. DOI: 10.1038/srep22729.

Sun Y, Chen CS, Fu J (2012a) Forcing stem cells to behave: a biophysical perspective of the cellular microenvironment. Annu Rev Biophys 41: 519-542.

Sun Y, Weng S, Fu J (2012b) Microengineered synthetic cellular microenvironment for stem cells. Wiley Interdiscip Rev Nanomed Nanobiotechnol 4: 414-427.

Suzuki S, Narita Y, Yamawaki A, Murase Y, Satake M, Mutsuga M, Okamoto H, Kagami H, Ueda M, Ueda Y (2010) Effects of extracellular matrix on differentiation of human bone marrow-derived mesenchymal stem cells into smooth muscle cell lineage: utility for cardiovascular tissue engineering. Cells Tissues Organs 191: 269-280.

Swetha M, Sahithi K, Moorthi A, Srinivasan N, Ramasamy K, Selvamurugan N (2010) Biocomposites containing natural polymers and hydroxyapatite for bone tissue engineering. Int J Biol Macromol 47: 1-4.

Takigawa H, Kitadai Y, Kuwai T, Yuge R, Tanaka S, Chayama K (2017) Mesenchymal stem cells promote epithelial-mesenchymal transition of colon cancer cells via direct cell-to-cell contact. Neoplasia 19: 429438 .

Takizawa N, Okubo N, Kamo M, Chosa N, Mikami T, Suzuki K, Yokota S, Ibi M, Ohtsuka M, Taira M (2017) Bone marrow-derived mesenchymal stem cells propagate immunosuppressive/anti-inflammatory macrophages in cell-to-cell contact-independent anddependent manners under hypoxic culture. Exp Cell Res 358: 411-420.

Tatárová Z, Abbuehl J, Maerkl S, Huelsken J (2016) Microfluidic co-culture platform to quantify chemotaxis of primary stem cells. Lab Chip 16: 19341945.

Thevenot PT, Nair AM, Shen J, Lotfi P, Ko C-Y, Tang L (2010) The effect of incorporation of SDF-1 $\alpha$ into PLGA scaffolds on stem cell recruitment and the inflammatory response. Biomaterials 31: 3997-4008. 
Thompson CL, Plant JC, Wann AK, Bishop CL, Novak P, Mitchison HM, Beales PL, Chapple JP, Knight MM (2017) Chondrocyte expansion is associated with loss of primary cilia and disrupted hedgehog signalling. Eur Cell Mater 34: 128-141.

Todd SJ, Farrar D, Gough JE, Ulijn RV (2007) Enzyme-triggered cell attachment to hydrogel surfaces. Soft Matter 3: 547-550.

Toma C, Pittenger MF, Cahill KS, Byrne BJ, Kessler PD (2002) Human mesenchymal stem cells differentiate to a cardiomyocyte phenotype in the adult murine heart. Circulation 105: 93-98.

Tondreau T, Meuleman N, Delforge A, Dejeneffe M, Leroy R, Massy M, Mortier C, Bron D, Lagneaux L (2005) Mesenchymal stem cells derived from CD133positive cells in mobilized peripheral blood and cord blood: proliferation, Oct4 expression, and plasticity. Stem Cells 23: 1105-1112.

Trento C, Bernardo ME, Nagler A, Kuçi S, Bornhäuser M, Köhl U, Strunk D, Galleu A, SanchezGuijo F, Gaipa G (2018) Manufacturing mesenchymal stromal cells for the treatment of graft-versus-host disease: a survey among centers affiliated with the European Society for Blood and Marrow Transplantation. Biol Blood Marrow Transplant 24: 2365-2370.

Tsimbouri PM, Childs PG, Pemberton GD, Yang J, Jayawarna V, Orapiriyakul W, Burgess K, GonzálezGarcía C, Blackburn G, Thomas D (2017) Stimulation of 3D osteogenesis by mesenchymal stem cells using a nanovibrational bioreactor. Nat Biomed Eng 1: 758770 .

Usunier B, Benderitter M, Tamarat R, Chapel A (2014) Management of fibrosis: the mesenchymal stromal cells breakthrough. Stem Cells Int 2014: 340257. DOI: 10.1155/2014/340257.

Varin A, Pontikoglou C, Labat E, Deschaseaux F, Sensebé L (2013) CD200R/CD200 inhibits osteoclastogenesis: new mechanism of osteoclast control by mesenchymal stem cells in human. PLoS One 8: e72831. DOI: 10.1371/journal.pone.0072831.

Vasandan AB, Jahnavi S, Shashank C, Prasad P, Kumar A, Prasanna SJ (2016) Human mesenchymal stem cells program macrophage plasticity by altering their metabolic status via a PGE 2-dependent mechanism. Sci Rep 6: 38308. DOI: 10.1038/srep38308.

Venkatesan J, Kim S-K (2014) Nano-hydroxyapatite composite biomaterials for bone tissue engineering a review. J Biomed Nanotechnol 10: 3124-3140.

Veronesi F, Borsari V, Sartori M, Orciani M, Mattioli-Belmonte M, Fini M (2018) The use of cell conditioned medium for musculoskeletal tissue regeneration. J Cell Physiol 233: 4423-4442.

Visnjic D, Kalajzic Z, Rowe DW, Katavic V, Lorenzo J, Aguila HL (2004) Hematopoiesis is severely altered in mice with an induced osteoblast deficiency. Blood 103: 3258-3264.

Wang T, Turhan M, Gunasekaran S (2004) Selected properties of $\mathrm{pH}$-sensitive, biodegradable chitosanpoly (vinyl alcohol) hydrogel. Polym Int 53: 911-918.
Wang W, Itaka K, Ohba S, Nishiyama N, Chung U-i, Yamasaki Y, Kataoka K (2009) 3D spheroid culture system on micropatterned substrates for improved differentiation efficiency of multipotent mesenchymal stem cells. Biomaterials 30: 2705-2715.

Wang Y, Volloch V, Pindrus MA, Blasioli DJ, Chen J, Kaplan DL (2007) Murine osteoblasts regulate mesenchymal stem cells via WNT and cadherin pathways: mechanism depends on cell-cell contact mode. J Tissue Eng Regen Med 1: 39-50.

Watson EC, Adams RH (2017) Biology of bone: the vasculature of the skeletal system. Cold Spring Harb Perspect Med 8. pii: a031559. DOI: 10.1101/ cshperspect.a031559.

Weber W, Fussenegger M (2012) Emerging biomedical applications of synthetic biology. Nature Rev Genet 13: 21-23.

Wei Y, Gong K, Zheng Z, Liu L, Wang A, Zhang L, Ao Q, Gong Y, Zhang X (2010) Schwann-like cell differentiation of rat adipose-derived stem cells by indirect co-culture with Schwann cells in vitro. Cell Prolif 43: 606-616.

Wenisch S, Stahl JP, Horas U, Heiss C, Kilian O, Trinkaus K, Hild A, Schnettler R (2003) In vivo mechanisms of hydroxyapatite ceramic degradation by osteoclasts: fine structural microscopy. J Biomed Mater Res A 67: 713-718.

Wingate K, Bonani W, Tan Y, Bryant SJ, Tan W (2012) Compressive elasticity of three-dimensional nanofiber matrix directs mesenchymal stem cell differentiation to vascular cells with endothelial or smooth muscle cell markers. Acta Biomater 8: 14401449.

Winkler IG, Barbier V, Wadley R, Zannettino A, Williams S, Lévesque J-P (2010) Positioning of bone marrow hematopoietic and stromal cells relative to blood flow in vivo: serially reconstituting hematopoietic stem cells reside in distinct nonperfused niches. Blood 116: 375-385.

Wislet-Gendebien S, Hans G, Leprince P, Rigo JM, Moonen G, Rogister B (2005) Plasticity of cultured mesenchymal stem cells: switch from nestin-positive to excitable neuron-like phenotype. Stem Cells 23: 392-402.

Wohrer S, Knapp DJ, Copley MR, Benz C, Kent DG, Rowe K, Babovic S, Mader H, Oostendorp RA, Eaves CJ (2014) Distinct stromal cell factor combinations can separately control hematopoietic stem cell survival, proliferation, and self-renewal. Cell Rep 7: 1956-1967.

Woodard JR, Hilldore AJ, Lan SK, Park C, Morgan AW, Eurell JAC, Clark SG, Wheeler MB, Jamison RD, Johnson AJW (2007) The mechanical properties and osteoconductivity of hydroxyapatite bone scaffolds with multi-scale porosity. Biomaterials 28: 45-54.

Wu C, Rankin EB, Castellini L, Fernandez-Alcudia J, LaGory EL, Andersen R, Rhodes SD, Wilson TL, Mohammad KS, Castillo AB (2015) Oxygen-sensing PHDs regulate bone homeostasis through the modulation of osteoprotegerin. Genes Dev 29:817-831. 
Xu C, Gao X, Wei Q, Nakahara F, Zimmerman SE, Mar J, Frenette P (2018) Stem cell factor is selectively secreted by arterial endothelial cells in bone marrow. Nat Commun 9:2449. DOI: 10.1038/s41467-018-047263.

Xu S, Menu E, Becker AD, Van Camp B, Vanderkerken K, Van Riet I (2012) Bone marrowderived mesenchymal stromal cells are attracted by multiple myeloma cell-produced chemokine CCL25 and favor myeloma cell growth in vitro and in vivo. Stem Cells 30: 266-279.

Xu S, Veirman K, Becker A, Vanderkerken K, Riet I (2018) Mesenchymal stem cells in multiple myeloma: a therapeutical tool or target? Leukemia 32: 15001514.

Yang C, Tibbitt MW, Basta L, Anseth KS (2014) Mechanical memory and dosing influence stem cell fate. Nat Mater 13: 645-652.

Yang S, Wei D, Wang D, Phimphilai M, Krebsbach $\mathrm{PH}$, Franceschi RT (2003) In vitro and in vivo synergistic interactions between the Runx2/Cbfa1 transcription factor and bone morphogenetic protein-2 in stimulating osteoblast differentiation. J Bone Miner Res 18: 705-715.

Yeatts AB, Choquette DT, Fisher JP (2013) Bioreactors to influence stem cell fate: augmentation of mesenchymal stem cell signaling pathways via dynamic culture systems. Biochim Biophys Acta Gen Subj 1830: 2470-2480.

Yeatts AB, Fisher JP (2010) Tubular perfusion system for the long-term dynamic culture of human mesenchymal stem cells. Tissue Eng Part C Methods 17: 337-348.

Yim EK, Pang SW, Leong KW (2007) Synthetic nanostructures inducing differentiation of human mesenchymal stem cells into neuronal lineage. Exp Cell Res 313: 1820-1829.

Yim EK, Sheetz MP (2012) Force-dependent cell signaling in stem cell differentiation. Stem Cell Res Ther 3: 41 DOI: 10.1186/scrt132.

Ylöstalo JH, Bartosh TJ, Coble K, Prockop DJ (2012) Human mesenchymal stem/stromal cells cultured as spheroids are self-activated to produce prostaglandin E2 that directs stimulated macrophages into an antiinflammatory phenotype. Stem Cells 30: 2283-2296.

Yona S, Kim KW, Wolf Y, Mildner A, Varol D, Breker M, Strauss-Ayali D, Viukov S, Guilliams M, Misharin A, Hume DA, Perlman H, Malissen B, Zelzer E, Jung S (2013) Fate mapping reveals origins and dynamics of monocytes and tissue macrophages under homeostasis. Immunity 38: 79-91.

Yousefi A-M, James PF, Akbarzadeh R, Subramanian A, Flavin C, Oudadesse H (2016) Prospect of stem cells in bone tissue engineering: a review. Stem Cells Int 2016: 6180487. DOI: 10.1155/2016/6180487.

Zanotti L, Angioni R, Calì B, Soldani C, Ploia C, Moalli F, Gargesha M, D'amico G, Elliman S, Tedeschi G (2016) Mouse mesenchymal stem cells inhibit high endothelial cell activation and lymphocyte homing to lymph nodes by releasing TIMP-1. Leukemia 30: 1143-1154.

Zhao F, Grayson WL, Ma T, Bunnell B, Lu WW (2006) Effects of hydroxyapatite in 3-D chitosangelatin polymer network on human mesenchymal stem cell construct development. Biomaterials 27: 1859-1867.

Zhao L, Liu L, Wu Z, Zhang Y, Chu PK (2012) Effects of micropitted/nanotubular titania topographies on bone mesenchymal stem cell osteogenic differentiation. Biomaterials 33: 2629-2641.

Zhao Y (2012) Light-responsive block copolymer micelles. Macromolecules 45: 3647-3657.

Zhou BO, Yue R, Murphy MM, Peyer JG, Morrison SJ (2014) Leptin-receptor-expressing mesenchymal stromal cells represent the main source of bone formed by adult bone marrow. Cell Stem Cell 15: 154-168.

Zimmermann EA, Schaible E, Bale H, Barth HD, Tang SY, Reichert P, Busse B, Alliston T, Ager JW, Ritchie RO (2011) Age-related changes in the plasticity and toughness of human cortical bone at multiple length scales. Proc Natl Acad Sci U S A 108: 14416-14421.

Zuk PA, Zhu M, Ashjian P, De Ugarte DA, Huang JI, Mizuno H, Alfonso ZC, Fraser JK, Benhaim P, Hedrick MH (2002) Human adipose tissue is a source of multipotent stem cells. Mol Biol Cell 13: 4279-4295.

\section{Discussion with Reviewer}

Reviewer: Given the wide distribution of MSCs and their diversity, there are likely to be a multitude of niches. Will each need to be analyzed separately or will there be common features?

Authors: Stem cells, including MSCs, require particular microenvironments to maintain themselves in vivo, otherwise known as niches (Schofield, 1978), where their stemness is protected and the stimulus for differentiation is triggered by cellular signaling with either tissue-adjacent cells, paracrine and endocrine signals from local or systemic sources, or external mechanical forces. Given the theoretically wide distribution of MSCs through several connective tissues in the organism (Crisan et al., 2008), it is reasonable to assume that the inherent chemistry, mechanical structure, and function of different tissues may influence the single MSC entity. Since native stem cell niches at distinct anatomical locations and developmental stages have remained a theoretical construct and criteria for the in vitro characterization of MSCs weakly delineate MSCs from other cell types, it remains challenging to compare naïve cells from different niches. However, increasing evidences indicate different transcriptome and differentiation capacity of MSCs-like cells obtained from diverse tissues (Sacchetti et al., 2016), while tissue-specific elements involved in MSC lineage decision still have to be revealed. Based on current knowledge, it 
can be assumed that both tissue-specific as well as common mechanisms control MSC fate in distinct niches. However, future research will be required to unravel these mechanisms, which will be also critical to resemble specific niche features in in vitro models. Recent technical advances in niche in vitro modelling will certainly play a pivotal role in understanding and elucidation of MSC physiology and regulation within different locations.

Reviewer: Are MSCs an in vitro artefact?

Authors: Most of the knowledge on MSC biology derives from in vitro studies, due to the current lack of sophisticated methods allowing to specifically track MSCs in vivo. As discussed in the article, in vitro cultures, despite being great mechanistic tools, can often manipulate the cell phenotype in favor of specific differentiation events, by exposing them to highly artificial situations, such as the unnatural 2D environment in monolayer cultures or chemical stimulation. These potentially stressful in vitro conditions provoke subcultured MSCs to adjust their physiology (Bara et al., 2014), while their stem cell features, inherent to rare cell population only, may disappear. Thus, regenerative properties of in vitro described MSCs are required to be validated in vivo with appropriate controls and reproducible protocols, which indeed only some studies have demonstrated until now. Nevertheless, in vitro amplified MSCs show therapeutic potential for certain clinical application, e.g. the treatment of graft-versus-host disease (Le Blanc et al., 2008; Ringdén et al., 2006; additional references), indicating therapeutic value of these cells independent of the fact that they might be an in vitro artefact.

\section{Additional References}

Le Blanc K, Frassoni F, Ball L, Locatelli F, Roelofs $\mathrm{H}$, Lewis I, Lanino E, Sundberg B, Bernardo ME, Remberger M, Giorgio D, Maarten E, Andrea B, Willem F, Olle R (2008) Mesenchymal stem cells for treatment of steroid-resistant, severe, acute graftversus-host disease: a phase II study. The Lancet 371: 1579-1586.

Ringdén O, Uzunel M, Rasmusson I, Remberger M, Sundberg B, Lönnies H, Marschall H-U, Dlugosz A, Szakos A, Hassan Z, Omazic B, Aschan J, Barkholt L, Le Blanc K (2006) Mesenchymal stem cells for treatment of therapy-resistant graft-versus-host disease. Transplantation 81: 1390-1397.

Editor's note: The Scientific Editor responsible for this paper was Chris Evans. 